\title{
Tonsil Surgery
}

Register studies of

Complications and Outcomes

\author{
Eirik Østvoll
}

DEPARTMENT OF OTORHINOLARYNGOLOGY

INSTITUTE OF CLINICAL SCIENCES

SAHLGRENSKA ACADEMY AT

THE UNIVERSITY OF GOTHENBURG

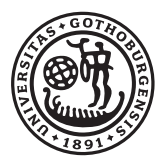

UNIVERSITY OF

GOTHENBURG

Gothenburg 2019 
Cover illustration by Pontus Andersson

Tonsil Surgery - Register Studies of Complications and Outcomes

(C) 20I9 Eirik Østvoll

eirik_ostvoll@hotmail.com

ISBN 978-9I-7833-636-4 (Print)

ISBN 978-9I-7833-637-I (pdf)

http://hdl.handle.net/2077/608I6

Printed by BrandFactory AB, Gothenburg, Sweden, 2019 
To Kiera and Yanti 



\title{
Tonsil Surgery \\ Register Studies of Complications and Outcomes
}

\author{
Eirik Østvoll \\ Department of Otorhinolaryngology, Institute of Clinical Sciences \\ Sahlgrenska Academy at the University of Gothenburg \\ Göteborg, Sweden
}

\begin{abstract}
Tonsillectomy is a commonly performed surgical procedure yet the evidence of the effect in patients with recurrent/chronic throat infections is unsatisfactory. Great variations exist in the reported rates of postoperative haemorrhage and mortality. The aims of this thesis were to investigate the effect of tonsillectomy for recurrent/chronic throat infections and determine the rates and risk factors for secondary haemorrhage as well as the mortality rate in Sweden.

METHODS/RESULTS: Paper I, a retrospective cohort study based on data from the Western Swedish Health Care Register (VEGA), compared the number of medical care visits for pharyngitis/tonsillitis in children and adults before (2 years), and after (3 years) tonsillectomy or no surgical treatment. The study showed a small significant reduction in medical care visits after tonsillectomy compared to no surgical treatment, with a difference in the change in mean yearly rate of -0.283 in children and -0.III in adults. All patients had few visits in the follow-up years regardless of surgical intervention. The effect of surgery was greater in children, in patients with higher number of medical care visits before surgery, and the first year of follow-up. In paper 2, a retrospective cohort study based on data from the National Patient Register in Sweden (NPR), the rates of readmission and reoperation for haemorrhage in Sweden (1987-2013) are described, as well as longitudinal changes related to trends in tonsil surgery practice. The overall readmission rate for haemorrhage was $2.6 \mathrm{I} \%$ and the reoperation rate was $0.84 \%$. Readmission rates for haemorrhage increased significantly from I.I2\% (I987) to $4.80 \%$ in 2013 and the increase was most pronounced for adults who underwent tonsillectomy for infectious disease. Male gender, increasing age, tonsillectomy and infectious indications were identified as independent risk factors for readmission and reoperation for haemorrhage. In paper III, the mortality rate (I/4I 236) after tonsil surgery in Sweden from 2004-20II was determined by matching the number of surgeries in the NPR with deaths within 30 days registered in the cause of death register (CDR). In paper $\boldsymbol{I V}$, a retrospective cohort study, registrations of surgical events and admissions for haemorrhage were retrieved from the NPR and the National Tonsil Surgery Register in Sweden (NTSRS) 2009-20I7, and subsequently matched and merged to increase the coverage and completeness of registrations. The inter-rater reliability between the registers in reporting admission for haemorrhage was determined ( $98.9 \%$ percent agreement and a Kappa value of o.88). The admission rate for haemorrhage was $4.2 \%$ in the NPR, $5.1 \%$ in the NTSRS and $4.5 \%$ in the merged cohort.

CONCLUSIONS: Tonsillectomy, in moderately or less affected children and adults, reduced the number of medical care visits for throat infections compared to no surgery but the reduction was small and not clinically relevant. The readmission rate for haemorrhage in Sweden increased from $1.12 \%$ (I987) to $4.80 \%$ in 2013 and have subsequently decreased $(3.2 \%$ in 20I7). Male gender, increasing age, tonsillectomy and infectious indications were identified as independent risk factors for admission and reoperation for haemorrhage. The mortality rate in Sweden after tonsil surgery (2004-20II) was I/4I 236. The NPR and the NTSRS showed close agreement in reporting of haemorrhage events and merging of data from the registers improved coverage and completeness of surgical events as well as haemorrhage events.
\end{abstract}

KEYWORDS: Tonsillectomy, tonsillotomy, tonsillitis, pharyngitis, postoperative haemorrhage, mortality

ISBN: $\quad 978-9 \mathrm{I}-7833-636-4 \quad$ (PRINT), ISBN: 978-9I-7833-637-I $\quad$ (E-PUB), http://hdl.handle.net/2077/608I6 


\section{Sammanfattning på svenska}

Tonsillektomi för återkommande halsinfektioner är en vanlig operation i Sverige. Evidensunderlaget för denna behandling är begränsat och bygger på studier utförda på få patienter och selekterade grupper. med ovanligt många årliga infektioner. Vid all tonsillkirurgi finns risk för komplikationer, och vanligast är blödning. Rapporterade siffror för blödningsandel vid tonsillkirurgi på godartade indikationer varierar mellan 0-29\%, och riskfaktorer för blödning har i flera studier visats vara: högre ålder, operation på män, operation vid infektionsrelaterade tillstånd, tonsillektomi jämfört med tonsillotomi, och vid alla operationstekniker som tillför värme till såret. Blödning kan vara allvarligt och vara dödligt.

Syftet med denna avhandling är att undersöka om tonsillektomi reducerar antal vårdbesök för halsinfektion samt i en nationell population över tid undersöka hur hög andel och vilka som blöder efter operationen. Ökad kunskap kring önskade och oönskade effekter vid tonsillkirurgi ger bättre förutsättningar för att välja rätt patienter till operativ behandling, och ge patienter rätt information inför beslut om operation.

Delarbete I är en retrospektiv kohortstudie baserad på data från Västra Götalands vårddatabas (VEGA). Studien jämför antal vårdbesök för halsinfektion före och efter tonsillektomi och jämför mot icke-opererade patienter. Studien som inkluderade 522 barn och II22 vuxna i varje grupp, visade signifikant lägre antal vårdbesök för halsinfektion efter tonsillektomi jämfört med före, och jämfört med icke opererade patienter. Man såg däremot också att alla patienter hade få värdbesök i uppföljningstiden oavsett om operation utfördes eller inte. Effekten av kirurgi var större hos patienter med många vårdbesök innan operation, hos barn jämfört med vuxna, och första uppföljningsåret jämfört med år två och tre. Uppsummerad så reducerade tonsillektomi antal vårdtillfällen för halsinfektioner, men skillnaden mot icke-opererade patienter var liten, och den kliniska nyttan således tveksam.

Delarbete II, en retrospektiv kohortstudie, studerade återinläggning för blödning efter tonsillkirurgi i Sverige 1987-20I3. Data från Patientregistret (NPR) inkluderade över 250000 tonsilloperationer och visade att 2,6I\% av patienterna återinlades för blödning inom 3I dagar efter operationen och att $0,84 \%$ re-opererades för blödning. Longitudinella analyser visade att andelen patienter återinlagda för blödning ökade från I,I2\% i 1987 till 4,8\% i 20I3, och den ökade mest för vuxna och för de som tonsillektomerades för infektionsrelaterade besvär. Manligt kön, högre ålder, halsinfektioner som indikation och tonsillektomi som metod identifierades som oberoende riskfaktorer för återinläggning för blödning.

I Delarbete III studerades mortalitet vid tonsillkirurgi i Sverige. Två dödsfall inom 30 dager efter kirurgi blev identifierat av 82527 operationer under perioden 2004-20II. Båda dödsfallen var barn, 
under 5 år, och dödsorsaken för båda var kvävning till följd av blödning. Den beräknade mortalitetsrisken var I/4I 263 operationer.

Delarbete IV är en jämförelse av data avseende antal tonsilloperationer och oplanerad inläggning för blödning efter operationen i Patientregistret (NPR) och det svenska kvalitetsregistret för tonsilloperation (NTSRS). Data presenterades för olika kohorter: data från respektive register, data som finns i båda registren (matchade data), och data som finns i någon av registren (merged data). Från dessa kohorter kunde en mer komplett sammanställning av antal operationer och blödningstillfällen skapas, och även blödningsandel kalkyleras longitudinellt. Täckningsgraden (registrerade operationer) till NPR beräknades till 94,6\%, och för NTSRS $75,4 \%$. Andelen patienter inlagda för blödning beräknades till 4,2\% i NPR, 5,I\% i NTSRS och 4,5\% i den samlade kohorten (merged data). Överensstämmelsen av blödningsandel mellan registren analyserades med lineär regressionsanalys, som visade nära korrelation för tonsillektomi som metod, men inte för övriga operationsmetoder. Överensstämmelsen mellan rapporterade blödningshändelser i båda register var hög med observerad värde $98,9 \%$ och beräknad Kappa värde o,88. 



\section{List of papers}

This thesis is based on the following studies, referred to in the text by their Roman numerals.

I. Østvoll E, Sunnergren O, Stalfors J.

Does tonsillectomy reduce medical care visits for pharyngitis/tonsillitis in children and adults? A retrospective cohort study from Sweden Accepted for publication in BMJ Open

II. Østvoll E, Sunnergren O, Stalfors J.

Increasing Readmission Rates for Hemorrhage after Tonsil Surgery: A Longitudinal (26 years) National Study

Otolaryngol Head Neck Surg 2018;158(1):167-176

III. Østvoll E, Sunnergren O, Ericsson E, Hemlin C, Hultcrantz E, Odhagen E, Stalfors J.

Mortality after tonsil surgery, a population study, covering eight years and 82,527 operations in Sweden

Eur Arch Otorhinolaryngol 2015;272(3):737-743

IV. Østvoll E, Sunnergren O, Stalfors J.

Tonsillar postoperative haemorrhage in Sweden 2009-2017, merging of data and evaluation of inter-rater reliability based on two national registers

Manuscript 



\section{Content}

INTRODUCTION

1.1 A GLANCE AT HISTORY 1

1.2 APPLIED ANATOMY 2

1.3 INCIDENCE RATES AND INDICATIONS 3

$\begin{array}{lll}1.4 & \text { SURGICAL METHODS AND TECHNIQUES } & 7\end{array}$

1.5 THE EFFECT OF SURGERY 8

$\begin{array}{lll}1.6 & \text { COMPLICATIONS } & 10\end{array}$

$\begin{array}{ll}\text { AIMS } & 15\end{array}$

Patients AND Methods

3.1 STUDY DESIGN - LEVEL OF EVIDENCE 16

3.2 UTILIZED SWEDISH MEDICAL REGISTERS 17

3.3 STUDY DESIGN AND SUBJECTS 21

3.4 STATISTICS 26

3.5 ETHICAL CONSIDERATIONS 31

RESULTS

4.1 PAPER I $\quad 32$

4.2 PAPER II 36

4.3 PAPER III $\quad 40$

4.4 PAPER IV 41

DISCUSSION 46

5.1 IS TONSILLECTOMY AN EFFECTIVE TREATMENT FOR RECURRENT/CHRONIC THROAT INFECTIONS? 46

5.2 WHAT IS THE RISK OF BLEEDING AFTER TONSIL SURGERY? 50

5.3 IS TONSILLECTOMY FOR RECURRENT/CHRONIC THROAT INFECTIONS WARRANTED? $\quad 54$

$\begin{array}{lll}5.4 & \text { LIMITATIONS } & 57\end{array}$

CONCLUSIONS

FUTURE PERSPECTIVES

ACKNOWLEDGEMENTS

REFERENCES

$\begin{array}{ll}\text { APPENDIX } & 79\end{array}$ 


\section{Abbreviations}

\begin{tabular}{|c|c|}
\hline $\mathrm{AHI}$ & Apnoea hypopnoea index \\
\hline CDR & Cause of death register \\
\hline $\mathrm{Cl}$ & Confidence interval \\
\hline ECA & External carotid artery \\
\hline ERS & European Respiratory Society \\
\hline GABHS & Group A beta-hemolytic streptococcus \\
\hline ICA & Internal carotid artery \\
\hline ICD & International Classification of Diseases \\
\hline NBHW & National Board of Health and Welfare \\
\hline NNT & Number needed to treat \\
\hline NOMESCO & Nordic Medico-Statistical Committee \\
\hline NPR & National Patient Register \\
\hline MSE & Mean squared error \\
\hline NTSRS & National Tonsil Surgery Register in Sweden \\
\hline \multirow[t]{2}{*}{ OECD } & The Organisation for Economic Co-operation and \\
\hline & Development \\
\hline OR & Odds ratio \\
\hline OSAS & Obstructive Sleep Apnoea syndrome \\
\hline PFAFA & $\begin{array}{l}\text { Periodic fever, aphthous stomatitis, pharyngitis and } \\
\text { adenitis syndrome }\end{array}$ \\
\hline PPV & Positive predictive value \\
\hline PSG & Polysomnography \\
\hline PTH & Post-tonsillectomy haemorrhage \\
\hline $\mathrm{RCT}$ & Randomized controlled trial \\
\hline ROC & Receiver operating characteristic \\
\hline RTT & Return to theatre \\
\hline
\end{tabular}




$\begin{array}{ll}\text { RR } & \text { Relative risk } \\ \text { SCD } & \text { Sickle cell disease } \\ \text { SDB } & \text { Sleep-disordered breathing } \\ \text { SFOHH } & \begin{array}{l}\text { Swedish Association for Otorhinolaryngology Head and } \\ \text { Neck Surgery (Svensk förening för Otorhinolaryngologi, } \\ \end{array} \\ & \text { Huvud- och Halskirurgi) } \\ \text { SKL } & \begin{array}{l}\text { Swedish Association of Local Authorities and Regions } \\ \text { (Sveriges Kommuner och Landsting) }\end{array} \\ \text { TE } & \text { Tonsillectomy } \\ \text { TEA } & \text { Adenotonsillectomy } \\ \text { TT } & \text { Tonsillotomy } \\ \text { TTA } & \text { Adenotonsillotomy } \\ \text { VEGA } & \text { The Western Swedish Health Care Register (Västra } \\ & \text { Götalandsregionens vårddatabas) }\end{array}$





\section{Introduction}

\subsection{A glance at history}

The first description of surgery on the palatine tonsils dates back to I000BC and the Hindu Sanskrit document Atharva-Veda. ${ }^{I}$ During the $19^{\text {th }}$ century anaesthesia became available, the guillotine, head mirror and mouth depressor was invented and the number of procedures increased along with widened indications. ${ }^{2}$ The indications for surgery were not well defined in the early literature, but probably ranged from treatment of recurrent or chronic infections and abscesses in the throat to prevention of both focal infections and systemic disease related to streptococcal infections in the pre-antibiotic era. The snare or the guillotine always resulted in tonsillotomy leaving part of the tonsillar capsule intact. The first published description of extracapsular dissection has been reported to be by the British Surgeon Georg Waugh in the Lancet 1909, but there are reports of earlier publications by Ballinger and Griffin in the US (I906) and usage of the method by the Greek physician Taptas before I903. ${ }^{34}$

It took almost 50 years for extracapsular tonsillectomy to be considered the only correct way of performing tonsil surgery. ${ }^{2}$ The shift from tonsillotomy to tonsillectomy led to a transition from ambulatory to inpatient surgery since the extracapsular dissection resulted in more serious bleeding and pain and required general anaesthesia. The introduction of antibiotics in the r 960 s resulted in a large decline in the number of surgeries performed. During the time period 1970-2000 an increase in the number tonsillectomies performed for upper airway obstruction was observed, and it is not clear whether this increase was caused by a true increase in the prevalence of the disease or more likely a higher awareness of the morbidity in this patient group..$^{5-7}$ In the late $20^{\text {th }}$ century, different techniques based on electrodissection were introduced, which added thermal energy to the surgical field to make dissection easier and faster and decrease perioperative haemorrhage. ${ }^{8-I I}$ With higher focus on effective utilization of health care resources and higher patient turnover, outpatient surgery was again introduced and is now standard of 
care in many countries. ${ }^{\mathrm{I} 2}{ }^{\mathrm{I}} 3$ At the beginning of the 2Ith century, tonsillotomy was re-introduced as a valid and, in some countries, the preferred surgical method for treating upper airway obstruction caused by tonsillar and adenoid hypertrophy. ${ }^{2}{ }^{\mathrm{I}}$

\subsection{Applied anatomy}

Figure I Hypertrophic tonsils removed by tonsillectomy

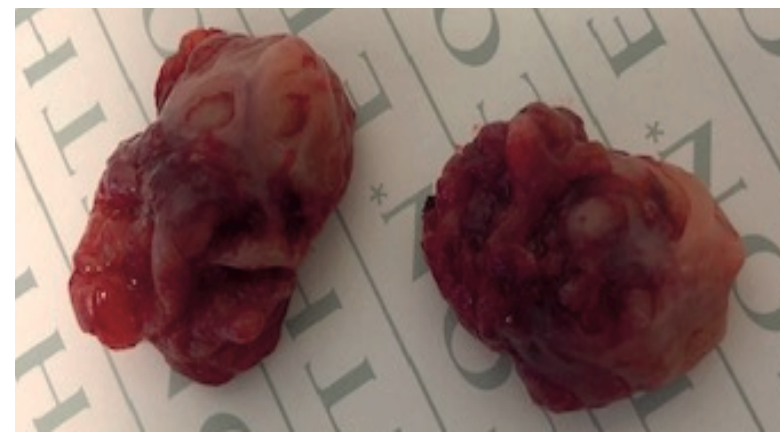

The palatine tonsils are paired collections of lymphoid tissue located in the tonsillar fossa attached to the lateral pharyngeal wall between the anterior and posterior tonsillar pillars, formed by the palatoglossal and palatopharyngeal muscles. Histologically, they have a stratified squamous epithelial lining with invaginations called crypts. The inside consists of aggregates of lymphoid tissue distributed in a follicular pattern and a stroma of connective tissue. The tonsils have both cellmediated and humoral immunological functions. ${ }^{15}$

The blood supply to the tonsils is mainly from branches of the external carotid artery. The lower pole is supplied by the dorsal lingual branch of the lingual artery and the ascending palatine and tonsillar arteries from the facial artery (main supply). The upper pole receives branches from the ascending pharyngeal artery and the descending palatine artery from the maxillary artery. ${ }^{167}$ The internal carotid artery runs lateral to the tonsillar fossa, with a variable described distance of between 6.0 and $28.6 \mathrm{~mm}$ in children, depending on weight and age. ${ }^{18}$ The ICA can have branches in the neck, and collaterals can exist between the ICA and ECA. ${ }^{19}$ Venous 
drainage occurs through the tonsillar and pharyngeal venous plexuses to the lingual and pharyngeal veins into the internal jugular vein. ${ }^{17} 20$

The pathophysiology of bleeding after tonsil surgery are not clear. Possible explanations are direct damage to arteries or branches during tonsillar dissection, most likely at the inferior pole where both the facial and lingual artery with branches may run close. ${ }^{21}$ Blunt or penetrating trauma to a vessel may cause a periarterial haematoma that may expand over time, become encapsulated and undergo necrosis, creating a space where the vessel can dilate into a pseudoaneurysm. These weakened vessel walls may later rupture and cause bleeding. ${ }^{2 .}$ It is also suggested that postoperative infection or enzymatic digestion of the healing wound may cause secondary haemorrhage. ${ }^{1922}$

\subsection{Incidence rates and indications}

Great variation is seen in tonsillectomy rates across countries. Van den Akker et al. reported rates varying between I9 (Canada) and II8 (Ireland) per Io 000 children and between I9 (Canada) and 76 (Finland) per Io ooo adolescents in $1998 .^{23}$ Windfuhr presented rates derived from an OECD database, ranging from 2.3 (Mexico 2013) to 25.4 (USA 2006) per Io 000 inhabitants of all ages. ${ }^{24}$ In Germany, regional differences in the prevalence of tonsillectomy in children and adolescents between states varied by a factor of 3, and tonsillectomy rates have decreased from 2007 , while tonsillotomy rates increased. ${ }^{24}$ In Sweden, an increase in the incidence rate of tonsil surgeries for patients $\leq \mathrm{I} 8$ years has been reported, from 22/I0 ooo person years in 1987 to 47/IO ooo person years in $2013{ }^{25}$ This increase was explained by a nearly fourfold increase in procedures performed for upper airway obstruction from 1987 to 2013 , and the proportion of tonsillotomy-based procedures out of all tonsil surgeries increased from II. $2 \%$ in 2006 to $55.1 \%$ in 2013 . In conclusion, we have an ongoing paradigm shift since the beginning of the 2Ist century in many countries, with an increasing proportion of patients being operated with (adeno)tonsillotomy for upper airway obstruction at the expense of tonsillectomy for recurrent/chronic tonsillitis. ${ }^{26}{ }^{27}$ 
Table 1

Indications for tonsillectomy. ${ }^{28} \square$ Evidence-based $\square$ Not evidence-based $\square$ some evidence

\begin{tabular}{|c|c|}
\hline Group I - Infectious diseases & Group IV - Atopies \\
\hline Recurrent tonsillitis & Bronchial asthma \\
\hline Peritonsillar abscess & Allergic rhinitis \\
\hline Infectious mononucleosis & Atopy \\
\hline $\begin{array}{l}\text { Vincent angina } \\
\text { Sinusitis } \\
\text { Bronchitis/Cough } \\
\text { Chronic otitis media with effusion }\end{array}$ & \multirow[b]{2}{*}{ Group V - Non-classifiable indications } \\
\hline Group II - Upper airway obstruction & \\
\hline $\begin{array}{l}\text { Tonsillar hypertrophy } \\
\text { Snoring }\end{array}$ & $\begin{array}{l}\text { Malocclusion, palatal cleft } \\
\text { Halitosis }\end{array}$ \\
\hline OSAS & Haemorrhagic tonsillitis \\
\hline \multirow[t]{2}{*}{ Rhinolalia } & Growth retardation \\
\hline & Nocturnal enuresis \\
\hline Group III - Focal and systemic diseases & Group VI - Special diseases \\
\hline $\begin{array}{l}\text { IgA nephropathy } \\
\text { Arthropathy (recurrent rheumatic fever) } \\
\text { Dermatoses (psoriasis) } \\
\text { Intestinal diseases (IBD, celiac disease) } \\
\text { Cardiac disease } \\
\text { PFAFA }\end{array}$ & $\begin{array}{l}\text { Down syndrome } \\
\text { Sickle cell anaemia } \\
\text { Cerebral palsy }\end{array}$ \\
\hline
\end{tabular}

The indications considered adequate for tonsil surgery today are usually divided into infectious diseases and upper airway obstructions. However, a variety of different indications have been described in the literature, as pointed out by the systematic review by Windfuhr published $2016 .^{28}$ This review describes the current status of the level of evidence for performing tonsillectomy for various indications and concludes that the only indication with a high level of evidence for tonsillectomy is sleep disordered breathing caused by upper airway obstruction. Further research is necessary to clarify the role of surgery in patients with psoriasis, IgA nephropathy, PFAFA and most importantly in patients with recurrent episodes of tonsillitis, with or without pharyngitis. For peritonsillar abscess, tonsillectomy seems justified only in patients with recurrent episodes or a significant history of tonsillitis. 


\section{Upper Airway obstruction}

Sleep-disordered breathing (SDB) in children is characterized by a broad spectrum of symptoms, ranging from snoring and partial airway obstruction to obstructive sleep apnoea syndrome with disruption of normal ventilation and sleep patterns. The prevalence of SDB in children is reported to be $4-11 \%$, while OSAS is less common, $1.2 \%-5.7 \%{ }^{29}$ Untreated SDB may result in cognitive challenges including learning and memory deficits, delayed language development, hampered executive functions, behavioural alterations and lower school performance. ${ }^{30} 31$ Nocturnal polysomnography (PSG) is considered the gold standard for the diagnosis of OSAS, but less comprehensive screening tests, such as nocturnal oximetry or ambulatory PSG, can be helpful. The sensitivity and specificity of a clinical evaluation and the use of the patient history for the diagnosis of OSAS in children has been shown to be unsatisfactory in several studies. ${ }^{30}$ An AHI index $>5$ has been used as a cut off to recommend tonsillectomy in children, but lower limits have also been suggested, as AHI $>1.5$ is considered statistically abnormal in children. ${ }^{30}$ According to the European Respiratory Society (ERS), a clinical suspicion of SDB in combination with SDB-related morbidity should be considered an indication for surgery if PSG is not available. ${ }^{32}$ SDB is more prevalent in children with sickle cell disease (SCD), and hypoxia promotes erythrocyte sickling and may worsen the morbidity with the disease. Adenotonsillectomy is most often indicated for children with SDB and SCD. ${ }^{33}$

In adults, tonsillectomy or tonsillotomy \pm uvulopalatopharyngoplasty is a treatment option for OSAS, in selected patients. ${ }^{3435}$

\section{Recurrent or chronic throat infections}

The most common indication for tonsillectomy has historically been recurrent acute tonsillitis or chronic tonsillitis. These terms are often used in combination and interchangeably, and no consensus exists regarding whether they comprise different pathophysiological entities. The definition of recurrent tonsillitis is clinically intuitive once a clear definition of an episode of tonsillitis is present. Acute tonsillitis is an infection in the tonsillar tissue caused by a virus (DNA double/single stranded or RNA singled stranded) or bacteria, most often group A betahaemolytic streptococci (GABHS). ${ }^{36}$ Chronic tonsillitis is often defined as symptoms of tonsillitis lasting longer than 3 months $^{37}$; however, no 
clinical or paraclinical tests exist to make this diagnosis, and some authors deny that chronic tonsillitis constitute an independent medical condition..$^{38}$ Ironically, in the ICDio coding system, a unique code exists for chronic tonsillitis $\left(\mathrm{J}_{350}\right)$ but not for recurrent acute tonsillitis.

Differentiating between tonsillitis and pharyngitis in the clinical setting can be difficult or impossible; hence, the term throat infection is often used to cover both tonsillitis and pharyngitis. ${ }^{37}$

Most national guidelines rely on the criteria first proposed by Paradise et al. to determine if tonsillectomy is indicated for recurrent throat infections and for defining an episode of acute throat infection. ${ }^{28} 3739$

Table 2

The Paradise criteria for tonsillectomy ${ }^{39}$

\begin{tabular}{ll}
\hline Number of episodes with tonsillitis & $\geq 7$ episodes during the last year \\
& $\geq 5$ episodes yearly in the last 2 years \\
& $\geq 3$ episodes yearly in the last 3 years \\
& Sore throat + minimum 1 additional criterion \\
Definition of an episode & $-\quad$ Temperature $>38.3 \mathrm{C}$ \\
$-\quad$ Cervical lymphadenopathy \\
$-\quad$ Tonsillar exudates \\
& Confirmed B-haemolytic \\
& Streptococcus group A
\end{tabular}

The Paradise criteria are stringent, and some countries have lowered the requirements for the number of episodes needed to qualify for tonsillectomy. ${ }^{28}$ In Sweden the guidelines for surgical treatment of recurrent tonsillitis are presented in table 3. 
Table 3

The Swedish guidelines for tonsillectomy (for infectious disease) ${ }^{40}$

Major criteria

- $\quad$ Sore throat caused by tonsillitis

- $\quad$ Sore throat symptoms severe enough to affect daily activities

- $\quad$ Epidemiological investigation performed and failure of medical treatment with antibiotics
Minor Criteria

- >3-4 episodes of tonsillitis within 12-24 months

- $\quad$ Recurrent fever in children without known focus

- $\quad$ Systemic disease worsened by tonsillitis

To qualify for tonsillectomy all major +1 minor criterion needs to be fulfilled.

\subsection{Surgical methods and techniques}

The surgical method of tonsillectomy involves dissection in the capsular plane of the tonsils and is defined as a total removal of all tonsillar tissue with the capsule, leaving the pharyngeal constrictor muscle to heal by secondary intention. Tonsillotomy is the removal of tonsillar tissue in the subcapsular plane and can be referred to by the synonyms subcapsular tonsillectomy or partial tonsillectomy. ${ }^{4 \mathrm{I}} \mathrm{A}$ variable amount of tonsillar tissue is removed, often the obstructive segment medial to the faucial pillars, leaving at least a rim of tonsillar tissue in the tonsillar fossa to protect the surrounding tissue. ${ }^{14} 4^{42}$ Both procedures can be performed in combination with adenoidectomy, removal of the lymphoid tissue within the mucous membrane of the roof and posterior wall of the nasopharynx..$^{15}$

Tonsillectomy has been the method of choice regardless of indication for several decades but is increasingly being replaced (from 2006-2007) in several European countries by tonsillotomy for upper airway obstruction in children. ${ }^{2425} 27{ }^{43}$ Tonsillotomy has shown comparable symptom relief and lower rates of postoperative haemorrhage and pain. ${ }^{4 \mathrm{I}} 4445$

Several different techniques are available for dissecting the tonsils. Techniques are usually divided into cold and warm, based on whether thermal energy is delivered to the surgical field to aid with dissection or haemostasis. The gold standard, often used as reference when comparing 
haemorrhage rates between surgical techniques, is the cold steel technique for dissection and haemostasis, and if necessary, surgical ties are used to ligate bleeding vessels. ${ }^{46}$ Warm techniques can provide better control of bleeding perioperatively and reduce operating time, whereas several studies have shown that cold techniques result in lower rates of secondary postoperative bleeding and pain. ${ }^{46-48}$ A dose-response effect between the amount of thermal energy delivered and the risk of collateral tissue injury and necrosis leading to secondary haemorrhage seems plausible. ${ }^{46} 49$

\section{Table 4}

Surgical techniques used for tonsillectomy/tonsillotomy in Sweden 2013-2015 (n=33 870). ${ }^{50}$ Data from the National Tonsil Surgery Register in Sweden

\begin{tabular}{llll} 
Dissection & \multicolumn{3}{l}{ Haemostasis } \\
\hline Cold steel & $41.0 \%$ & Compression with packs only & $24.1 \%$ \\
Radiofrequency & $38.0 \%$ & Injection with epinephrine & $3.4 \%$ \\
Diathermy scissors & $14.3 \%$ & Unipolar diathermy & $2.4 \%$ \\
Ultracision & $1.0 \%$ & Bipolar diathermy & $44.8 \%$ \\
Other techniques & $2.0 \%$ & Ties & $0.6 \%$ \\
Multiple techniques & $3.7 \%$ & Suture ligature & $0.4 \%$ \\
& & Radiofrequency & $5.3 \%$ \\
& & Other technique & $5.3 \%$ \\
& & Multiple techniques & $13.7 \%$
\end{tabular}

In Sweden cold steel dissection (69.I/74.3\%) combined with compression and bipolar diathermy $(56.2 / 47.9 \%)$ for haemostasis is the most commonly used technique for tonsillectomy/adenotonsillectomy, while radiofrequency $(85.5 / 77.7 \%)$ in combination with compression and bipolar diathermy $(40.0 / 32.4 \%)$ is the most frequently used technique for tonsillotomy/adenotonsillotomy. ${ }^{50}$

\subsection{The effect of surgery}

Estimating the effect of tonsil surgery can be done with different measures depending on the indication for surgery.

\section{Tonsillectomy/tonsillotomy for upper airway obstruction}

In children with sleep-related breathing disorders (SDB) or obstructive 
sleep apnoea syndrome (OSAS) a reduction of the AHI to $<$ I, as measured by PSG before/after surgery, is often considered to be the definition of a successful intervention. Alternative measures of effect are patient satisfactory scores and quality of life evaluations. Friedman et al. found a success-rate of approximately $60 \%$ (reducing AHI to $<_{\mathrm{I}}$ ) with adenotonsillectomy (TEA) in paediatric patients in their meta-analysis from 2009, while other studies have reported higher cure rates ${ }^{41} 5^{5} 5^{2}$ Several studies have shown comparable success rates for tonsillectomy and tonsillotomy with regard to the reduction in the AHI index, patient satisfactory scores and quality-of-life end points. ${ }^{4 \mathrm{5I}}$

In adults, simple tonsillectomy can be relevant and successful in decreasing the AHI index, but the effect seems to be highly dependent on patient selection (higher chance of success with normal weight and large tonsils). .354

\section{Tonsillectomy for recurrent/chronic tonsillitis}

The effect of tonsillectomy for recurrent acute tonsillitis is often measured by the ability to reduce the number and/or severity of episodes of throat infection or days with sore throat. The most comprehensive meta-analysis to date, published by Burton et al. in 20I4, concluded that (adeno)tonsillectomy reduces the number of episodes with sore throat in children, but the effect is only seen during the first year after surgery and is of a modest size. ${ }^{37}$ Severely affected children seem to benefit more from the procedure. Insufficient data were available to draw firm conclusions on the effect in adults. The updated clinical guideline for tonsillectomy in children developed by the American Academy of Otolaryngology - Head and Neck Surgery Foundation published 2019 makes a strong recommendation for watchful waiting in children not fulfilling the Paradise criteria, since no clinically meaningful improvements are shown in patients less affected. ${ }^{55}$ Windfuhr et al. emphasized, in another systematic review from 20I6, that the role of tonsillectomy for treating recurrent throat infections is unclear. ${ }^{28}$ The evidence for the effect of surgery in reducing episodes of throat infection lean heavily on the randomized controlled trials in children by Paradise et al. $1984^{39}$ and $2002^{56}$, Van Staiij et al. $2004^{57}$ and Lock et al. 20I0 ${ }^{58}$. Only two RCTs, Alho et al. ${ }^{59}$ and Koskenkorva et al. ${ }^{60}$, have investigated the effect in adults. 
It is not obvious that the effect measures presented above are the only way to evaluate the outcomes of surgery. Reported patient satisfactory scores are generally high; according to the National Tonsil Surgery Register in Sweden (NTSRS) 77\% of patients reported that their symptoms were gone after tonsillectomy for recurrent tonsillitis, while $96.9 \%$ reported that their symptoms were gone or almost gone (19972008). ${ }^{61}$ Other studies have reported improvement in both disease-specific and global quality of life, for children and adults, after tonsillectomy in this setting. ${ }^{62-64}$

\subsection{Complications}

Pain, dehydration, postoperative nausea and vomiting, delayed feeding and postoperative haemorrhage are the most common complications of tonsil surgery. 55 65 66 Rare complications ranging from permanent dysphagia, taste disturbance, direct carotid artery damage, atlantooccipital luxation and death are described in the literature. ${ }^{66-72}$ Revisits to medical care facilities or readmissions for complications are not uncommon. ${ }^{73}$

\section{Table 5}

Reported complications of tonsil surgery ${ }^{74}$

\begin{tabular}{ll} 
Common & Rare \\
\hline Throat pain & Hypoxia or desaturation \\
Dehydration/fatigue & Taste disturbance \\
Haemorrhage & Pneumonitis or pneumonia \\
Fever & Purulent neck infection \\
Nausea/vomiting & Internal carotid injury \\
Delayed feeding & Internal Jugular vein thrombosis \\
Infection (tonsillar bed) & Respiratory failure \\
& Atlantoaxial subluxation \\
& Velopharyngeal insufficiency \\
& Damage to the Temporomandibular joint \\
& Injury to the lip, teeth, uvula, tongue \\
& Tonsillar remnants req. revision surgery \\
& Dysphonia \\
& Blood transfusion \\
& Death
\end{tabular}




\section{Postoperative pain}

Tonsillectomy is described as one of the most painful minor surgical interventions across all surgical specialties and seems to be particularly unpleasant for adults. ${ }^{75} 76$ A recent German study found female gender, age $<20$ years, a lack of specific pain counselling, preoperative chronic pain, and opioid administration in the recovery room to be independent predictors of higher experiences of postoperative pain. ${ }^{76}$ Pain was greatest for patients I8-20 years of age. The same study suggested that many patients do not receive adequate pain management after tonsillectomy. Most patients experience decreasing pain after the third postoperative day, but different pain courses have been described in the postoperative period. ${ }^{77}$ There is evidence for greater pain after the use of diathermy compared to cold dissection, and lesser pain after tonsillotomy compared to tonsillectomy..$^{41}{ }^{78}$ Cardozo et al. reported on a dose-response relationship between the amount of applied diathermy energy intraoperatively and postoperative pain. ${ }^{79}$ Different regimens for pain control are in use; most consist of paracetamol in combination with NSAIDs, codeine, tramadol or morphine/oxycodon. ${ }^{80}{ }^{81}$ Ericsson et al. have previously published Swedish guidelines for the treatment of pain after tonsil surgery in children, and recommend paracetamol in combination with NSAIDs and if needed, clonidine in favour of morphine, to avoid respiratory side effects ${ }^{82}$ Codeine is not advisable in children due to unreliable metabolism..$^{52}$

\section{Postoperative haemorrhage}

The most common and potential serious complication of tonsil surgery is haemorrhage. Definitions of haemorrhage range from anamnestically recorded blood-tinged sputum to haemodynamic failure from massive bleeding or asphyxia due to blood in the airway. ${ }^{83}$ Postoperative haemorrhage is divided into primary (before discharge or within 24 hours) and secondary haemorrhage (after discharge or after 24 hours). ${ }^{72} 84$ ${ }^{85}$ The rates of readmission, revisit to the hospital or reoperation to secure haemostasis are measures often used to report the risk of haemorrhage. ${ }^{73}$ 838586 Accordingly, in papers II and IV of this thesis, secondary haemorrhage is defined as admission/readmission for haemorrhage. 
Reported haemorrhage rates after tonsillectomy (+/- adenoidectomy)

\begin{tabular}{|c|c|c|c|c|c|}
\hline Author & $\begin{array}{l}\text { Year } \\
\text { (publ.) }\end{array}$ & Country & $\begin{array}{l}\text { Primary } \\
\text { haemorrhage }\end{array}$ & $\begin{array}{l}\text { Secondary } \\
\text { haemorrhage }\end{array}$ & $\begin{array}{l}\text { Overall } \\
\text { haemorrhage }\end{array}$ \\
\hline $\begin{array}{l}\text { Bhattacharyya } \\
\text { et al. }{ }^{87}\end{array}$ & 2001 & USA & $0.7 \%$ & $4.4 \%$ & $5.1 \%$ \\
\hline Windfuhr ${ }^{84}$ & 2005 & Germany & & & $2.86 \%{ }^{*}$ \\
\hline Lowe et al. ${ }^{88}$ & 2007 & $\begin{array}{l}\text { England, } \\
\text { N. Ireland }\end{array}$ & $0.6 \%$ & $3.0 \%$ & $3.5 \%$ \\
\hline Walker et al. ${ }^{89}$ & 2007 & Australia & $0.4 \%$ & $4.6 \%$ & $5.0 \%$ \\
\hline Kvaerner KJ ${ }^{90}$ & 2009 & Norway & & $0.5 \%$ & \\
\hline $\begin{array}{l}\text { Tomkinson et } \\
\text { al. }{ }^{85}\end{array}$ & 2010 & Wales & $0.9 \%$ & $2.6 \%$ & $3.5 \%$ \\
\hline Sarny et al. ${ }^{83}$ & 2011 & Austria & & & $15 \%$ \\
\hline Tolska et al. ${ }^{91}$ & 2013 & Finland & $1.3 \%$ & $13.2 \%$ & $14.5 \%$ \\
\hline Ikoma et al. ${ }^{92}$ & 2014 & Japan & 1.6 & 10.0 & $11.6 \%$ \\
\hline Seshamani ${ }^{66}$ & 2014 & USA & & $6.37 \%$ & \\
\hline $\begin{array}{l}\text { Söderman et } \\
\text { al. }{ }^{48}\end{array}$ & 2015 & Sweden & $3.2 \%$ & $9.4 \%$ & $12.6 \%$ \\
\hline Windfuhr ${ }^{24}$ & 2016 & Germany & & & $5.98 \%$ \\
\hline
\end{tabular}

* Including children operated with only adenoidectomy

Reported rates of postoperative haemorrhage varies between 0-29.I\% in the literature. ${ }^{93}$ This most likely reflects not only discrepancies in definitions of haemorrhage and study designs, but also true differences related to variations in surgical populations regarding risk factors for haemorrhage.

Ideally studies on postoperative haemorrhage should describe both the frequency and severity of the bleedings. Sarny et al. have published one of the most comprehensive classification of haemorrhage events after tonsil surgery in Austria, with frequencies, day of onset, severity with 7 categories ranging from patient-reported blood-tinged sputum to death caused by bleeding, and information on risk factors for haemorrhage. ${ }^{83} 94$ Several other publications as well have addressed risk factors for postoperative haemorrhage after tonsillectomy.47-49 78929596 


\begin{tabular}{ll} 
Patient factors & Surgical factors \\
\hline Male gender & Infectious indication* \\
Increasing age & Tonsillectomy > tonsillotomy \\
& Warm technics for dissection \\
& Warm technics for haemostasis \\
& Experience of the surgeon* \\
\hline
\end{tabular}

"Discrepancy between studies

\section{Patient factors}

Several independent studies have found a higher risk of postoperative haemorrhage in males compared to females and increasing risk with age. Tomkinson et al. reported an adjusted OR of I.9 for return to theatre due to bleeding in males, and an OR of I.5 and 3.3 in patients older than I2 years, for primary and secondary haemorrhage respectively. ${ }^{85}$ Lowe et al. presented a risk model for post-tonsillectomy haemorrhage (PTH) based on data from the national prospective tonsillectomy audit in England, showing a lower risk of haemorrhage in females (adjusted OR 0.82) and a higher risk with increasing age (adjusted OR I.02 per year) ${ }^{88}$ Data from Sweden on readmissions for haemorrhage after tonsil surgery (all methods) from $2013-2015$ found rates of $5.3 \%$ in males, and $5.0 \%$ in females; $2.7 \%$ in patients $<\mathrm{I} 8$ years and II. $5 \%$ in patients $\geq$ I 8 years. ${ }^{50}$ However, these data were unadjusted for other risk factors for haemorrhage. No definite explanation for the influence of age and gender on the risk of haemorrhage has been presented.

Use of NSAID to treat postoperative pain has been suggested to increase the risk of both primary and secondary haemorrhage. Riggin et al., found no significantly increased risk of haemorrhage after administration of NSAID in a large systematic review published 2013. ${ }^{97}$

A systematic review from 2017 found no difference in post tonsillectomy haemorrhage rates (PTH) following paediatric tonsil surgery in children on a restricted diet after surgery compared to children on unrestricted diets. $^{98}$ 


\section{Surgical factors}

The indication for surgery, surgical method, surgical technique and experience of the surgeon could theoretically influence the risk of haemorrhage and there are studies confirming that these variables matter; to what extent, however, is a debate that is still ongoing. Lowe et al. showed higher rates of postoperative haemorrhage in patients undergoing surgery for recurrent/chronic tonsillitis and peritonsillar abscess compared to patients being operated for upper airway obstruction. ${ }^{88}$ Sarny et al. however found no difference in the risk of haemorrhage related to indications, but tonsillectomy for recurrent tonsillitis was associated with a higher risk of serious bleeding. ${ }^{83} \mathrm{~A}$ large retrospective study from Sweden failed to show any influence of indication on the risk of primary haemorrhage. ${ }^{99}$

Introducing thermal energy to the operating field increase the risk of secondary haemorrhage, according to most studies. Sarny et al., Tomkinson et al. and Lowe et al. all reported significantly higher haemorrhage rates with all warm techniques compared to cold steel techniques. ${ }^{49}{ }^{83} 85$ In Sweden a large retrospective study by Söderman et al. came to the same conclusion. ${ }^{8}$

Tonsillotomy bleeds less than tonsillectomy; a recent systematic review by Zhang et al. found a $79 \%$ lower odds of secondary haemorrhage after tonsillotomy compared to tonsillectomy. ${ }^{4 \mathrm{I}}$ In Sweden, Odhagen et al. observed a higher odds of readmission for haemorrhage after tonsillectomy compared to tonsillectomy (Adjusted OR 3.9I).

No consensus has been reached as to whether the experience of the operating surgeon influences the risk of haemorrhage. Tomkinson et al. found a higher risk of reoperation for primary haemorrhage when the surgeon was a junior trainee, but found no difference with regards to secondary haemorrhage risk. ${ }^{85}$ Lowe et al. found no significant difference in haemorrhage rates related to the grade of the surgeon, while Sarny et al. found lower haemorrhage rates in operations performed by surgeons undergoing training (registrars). ${ }^{83} 88$ 


\section{Aims}

The overall aim of this thesis was to investigate whether tonsillectomy is an effective treatment for throat infections and determine the rate of secondary haemorrhage and mortality after tonsil surgery, as well risk factors for bleeding. This will form the basis for a risk-benefit discussion of the relevancy of tonsillectomy for recurrent throat infections.

\section{Paper I Does tonsillectomy reduce medical care visits for pharyngitis/tonsillitis in children and adults? A retrospective cohort study from Sweden}

To investigate whether tonsillectomy reduces the number of medical care visits for pharyngitis and tonsillitis in children and adults.

\section{Paper II Increasing Readmission Rates for Hemorrhage after Tonsil Surgery. A Longitudinal (26 years) National Study}

To determine the readmission and reoperation rates after tonsil surgery in a national population over time and identify risk factors for haemorrhage.

\section{Paper III Mortality after tonsil surgery, a population study, covering eight years and 82,527 operations in Sweden}

To identify the mortality rate after tonsil surgery and causes of death.

\section{Paper IV Tonsillar postoperative haemorrhage in Sweden 2009-2017, merging of data and evaluation of inter-rater reliability based on two national registers}

To determine the inter-rater reliability (agreement) between two medical care registers in reporting admission for haemorrhage. To describe a method of combining data from two registers to improve coverage and completeness of surgeries and haemorrhage events available for calculating the rate of secondary haemorrhage. 


\section{Patients and methods}

\subsection{Study design - level of evidence}

The studies included in this thesis are based on data retrieved from medical registers and are best described as retrospective cohort studies. The defining characteristics of cohort studies is the tracking of patients forward in time from exposure to outcome, in a prospective or retrospective manner. ${ }^{100}$ Historically, well-designed retrospective cohort studies have been defined as evidence grade III depending on the preferred classification system and the nature of the problem being investigated. ${ }^{\text {IOI }}$ The chosen study design is appropriate when studying complications of an intervention (papers II, IV) and when evaluating rare events (paper III). ${ }^{102}$ Single randomized clinical trials are often underpowered to adequately address adverse effects, and the reporting of relative risks of harm caused by medical or surgical interventions are found to be comparable between randomized and non-randomized studies. ${ }^{103}$ Observational studies, in general, are often more informative in describing what is achieved in daily medical practice outside a controlled research environment. ${ }^{103} \mathrm{We}$ have strived to transparently report all results in papers I-IV in accordance with the well-recognized STROBE statement. ${ }^{\mathrm{I04}}$

Randomised controlled trials (RCTs) are the preferred study design when investigating the beneficial effect of a medical or surgical treatment because they address confounding by indication and selection bias. ${ }^{\text {IOI }}$ RCTs with the aim of investigating the effect of tonsillectomy for recurrent/chronic throat infections have been conducted, but they are few, and they are limited by small sample sizes, heterogeneity in design, a high degree of crossover or short follow-up. No retrospective cohort study has previously been performed comparing the effect of tonsillectomy with expectancy in a matched control group (I). To design and conduct RCTs to investigate the effect of an already well-established surgical method is challenging for ethical and practical reasons. Tonsil surgery has been performed for over 3000 years, and no systematic approach was undertaken to ensure the appropriateness or safety of the 
procedure when it was new. Until recently, no applicable system for such evaluations existed. In 2009, the IDEAL framework was presented in the Lancet with the aim of assisting in the assessment of new surgical procedures. ${ }^{105}$ The vital importance of medical registers or databases in this assessment was emphasized in an updated version published 20I8. ${ }^{106}$ Pilot studies followed by RCTs are still considered the best way to address the outcomes and adverse effects of new surgical procedures, but evaluating trends in indications and outcomes and identifying rare events and later outcomes is best achieved through medical registers. ${ }^{\mathrm{IO}}$

All data in the papers included in this thesis are derived from Swedish medical registers.

\subsection{Utilized Swedish medical registers}

\section{The National Patient Register (NPR)}

The NPR provides statistics on diseases and treatments in Swedish specialized healthcare and is currently administered by the National Board of Health and Welfare (NBHW), a government agency under the jurisdiction of the Ministry of Health and Welfare. The NPR started as a hospital discharge register in I964. In the beginning, only psychiatric care from a few counties was included. In I983, approximately $85 \%$ of somatic inpatient care nationwide was estimated to be included, and the register is considered to be complete for all inpatient care since $1987 .{ }^{107}$ In 1997 , surgical day care procedures were included, and from 200I, reporting of hospital-based outpatient procedures was mandatory. The register is considered to currently (2OII) cover close to $80 \%$ of hospital-based outpatient care. ${ }^{107}$ The coverage of private caregivers is uncertain despite reporting being mandatory by law. Primary care is not systematically reported to the register. The NPR contains patient-related data, including the unique personal identity number, medical data on diseases and procedures as well as administrative data on admission, discharge, level of care and healthcare provider. The coding of diseases and medical conditions are currently based on a Swedish version of the ICD-IO coding system and, historically, on the prior versions, ICD-9, ICD-8 and ICD-7. Procedures are coded according to the NOMESCO codes for surgical 
procedures. ${ }^{108}$ In the validation of the inpatient section of the register conducted by Ludvigsson et al. 20II, high PPVs (85-95\%) for the evaluated diagnoses were found. ${ }^{107}$

\section{The National Tonsil Surgery Register in Sweden (NTSRS)}

The NTSRS was founded in 1997 by the Swedish Association of Otorhinolaryngology Head and Neck Surgery (SFOHH) with the ambition to improve ENT care in Sweden. The register is administered by a steering committee of academically and clinically active ENT consultants on behalf of the SFOHH and is funded by the Swedish Association of Local Authorities and Regions (SKL). The register was revised in 2009 with the addition of new items on surgical technique and patient-related outcome measures and currently contains approximately 50 variables for each patient and over 100000 surgeries since the 2009revision.

Data retrieval in the register are based on questionnaires, with the operating surgeons and the patients as respondents. ${ }^{50}$ In summary, the surgeons report on details of the surgical procedure, indications and primary haemorrhage, while the patients report on admission for haemorrhage (secondary haemorrhage), postoperative infection, pain and symptom relief. A summary of the data-collection is shown in table 8 and all three questionnaires are provided in the appendix.

The steering committee has published several yearly reports based on statistics from the register and initiated improvement programmes in individual clinics to reduce the rates of postoperative haemorrhage. ${ }^{\text {I09-III }}$ Several studies based on data from the register have been published within the last IO years. ${ }^{25} 424448506199$ II2-II4 All participating surgical units have access to their own data and the opportunity to compare outcomes with other clinics and national numbers. 
Table 8

A summary of data collection in the National Tonsil Surgery Register in Sweden (NTSRS)

\begin{tabular}{|c|c|c|}
\hline Questionnaires & Respondent & Variables \\
\hline Day of surgery & Surgeons & $\begin{array}{l}\text { Age, gender, main indication, surgical method, } \\
\text { surgical technique for dissection, surgical technique } \\
\text { for haemostasis, type of operation (primary or } \\
\text { reoperation), level of care (outpatient or inpatient), } \\
\text { primary haemorrhage (including intervention). }\end{array}$ \\
\hline 30 days & $\begin{array}{l}\text { Patients/ } \\
\text { caregiver }\end{array}$ & $\begin{array}{l}\text { Contact to health care facility due to haemorrhage } \\
\text { (including number of days since surgery), admission } \\
\text { due to haemorrhage (including name of hospital), } \\
\text { reoperation due to haemorrhage, infection after } \\
\text { surgery (including information on which infection), } \\
\text { contact with health care facility due to infection, } \\
\text { contact with health care facility due to pain, days } \\
\text { with use of analgesics, question about received } \\
\text { information with regards to the surgical experience } \\
\text { (if not corresponding, what differed?), question } \\
\text { about access to the webpage } \\
\text { (www.tonsilloperation.se). }\end{array}$ \\
\hline 6 months & $\begin{array}{l}\text { Patients/ } \\
\text { caregiver }\end{array}$ & $\begin{array}{cc}\text { Question about symptom relief: } \\
-\quad \text { My symptoms are gone } \\
-\quad \text { My symptoms have improved } \\
-\quad \text { My symptoms are unchanged } \\
-\quad \text { My symptoms have worsened } \\
\text { Question about other new complaints after surgery. }\end{array}$ \\
\hline
\end{tabular}

\section{The Western Swedish Health Care Register (VEGA)}

VEGA is a medical database containing information on all medical care provided in the Västra Götaland region in Sweden and currently covers I.6 million inhabitants. This database was created to ease the surveillance of requested and provided medical care in the region. The register includes information from both private and public caregivers, within primary care and specialized inpatient and outpatient care. Reporting to the register is a prerequisite for reimbursement from the regional health care authorities, and hence, the coverage is considered close to complete. However, no formal validation of the quality of coding or coverage has been published. Data on specialized in- and outpatient care are equal to the data reported to the NPR. Diseases or medical conditions are reported to VEGA based on the Swedish version of the ICD coding system (ICDIO since 1997) and the reporting of procedures based on the NOMESCO classification of surgical procedures. ${ }^{108}$ Additional variables include the 
personal identity number of the patients, place of residence, information on the general practitioner of the patient, and the date and place of contact for medical care visits. The register is managed by the local health care authorities. (information on the register is available in Swedish at www.vgregion.se, or through personal contact to the county council, Region Västra Götaland, head office)

\section{The Cause of Death Register (CDR)}

The CDR contains information on all deaths of Swedish residents, in Sweden and abroad. ${ }^{115}$ Since 20I2, the register also contains information on deaths of non-Swedish residents in Sweden. The CDR is currently administrated by the NBHW and each year cause-of-death-statistics are published. The register is considered complete and $96 \%$ of the individuals in the registers have a specific underlying cause of death recorded. Data is available electronically back to I952. The register is based on ICD coding and contains data on place of birth, nationality, gender, marital status, place of residence, date of death, underlying and contributing causes of death, place of death, autopsy type, and data on surgery within 4 weeks of death. ${ }^{\mathrm{II}}$ When a person in Sweden dies, a medical death certificate must be submitted to the NBHW within 3 weeks, and this certificate, together with additional information from the tax authority, forms the basis for the data recorded in the register. 


\subsection{Study design and subjects}

\section{Paper I}

This is a comprehensive retrospective cohort study based on data from the VEGA register. First, data for all patients with a medical care visits coded as tonsillitis or pharyngitis from 201 I to 2017 were retrieved. From this population, two groups were formed. All patients who underwent tonsillectomy or adenotonsillectomy (only children) based on the indication chronic tonsillitis $\left(\mathrm{J}_{350}\right)$ between 2013 and 2016 constituted the intervention group. A control group was created from patients who had medical care visits for tonsillitis or pharyngitis from 2013-20I6 but who did not undergo tonsil surgery. One of the visits in the control group was randomly classified as a fictious tonsillectomy to enable comparison with the intervention group. The intervention and control groups were matched I:I on gender and number of medical care visits in the 2-year period before surgery/no surgery, and as close as possible on age (I:I on age group). Patients with previously registered tonsil surgery between 2000 and 2012 were excluded from both groups. One medical care visit was subtracted for patients in the intervention group to adjust for the visit related to scheduling of the surgery. Only one medical care visit was counted for each date and if conflicts occurred in coding, diagnostic codes from visits in specialized care was prioritized over primary care and acute tonsillitis codes were prioritized over acute pharyngitis codes.

The intervention and control groups were divided into three categories based on the number of medical care visits for tonsillitis/pharyngitis in the 2-year period before surgery/no surgery: Category A (I-3 visits), category B (4-6 visits), category C ( $7^{+}$visits). The follow-up period ranged from one to three years.

The primary outcome variable in the study was changes in yearly mean rates of medical care visits due to tonsillitis or pharyngitis before and after (adeno)tonsillectomy compared to the rates in patients who did not have surgery. 
Figure 2 Flow-chart of the study design in paper I

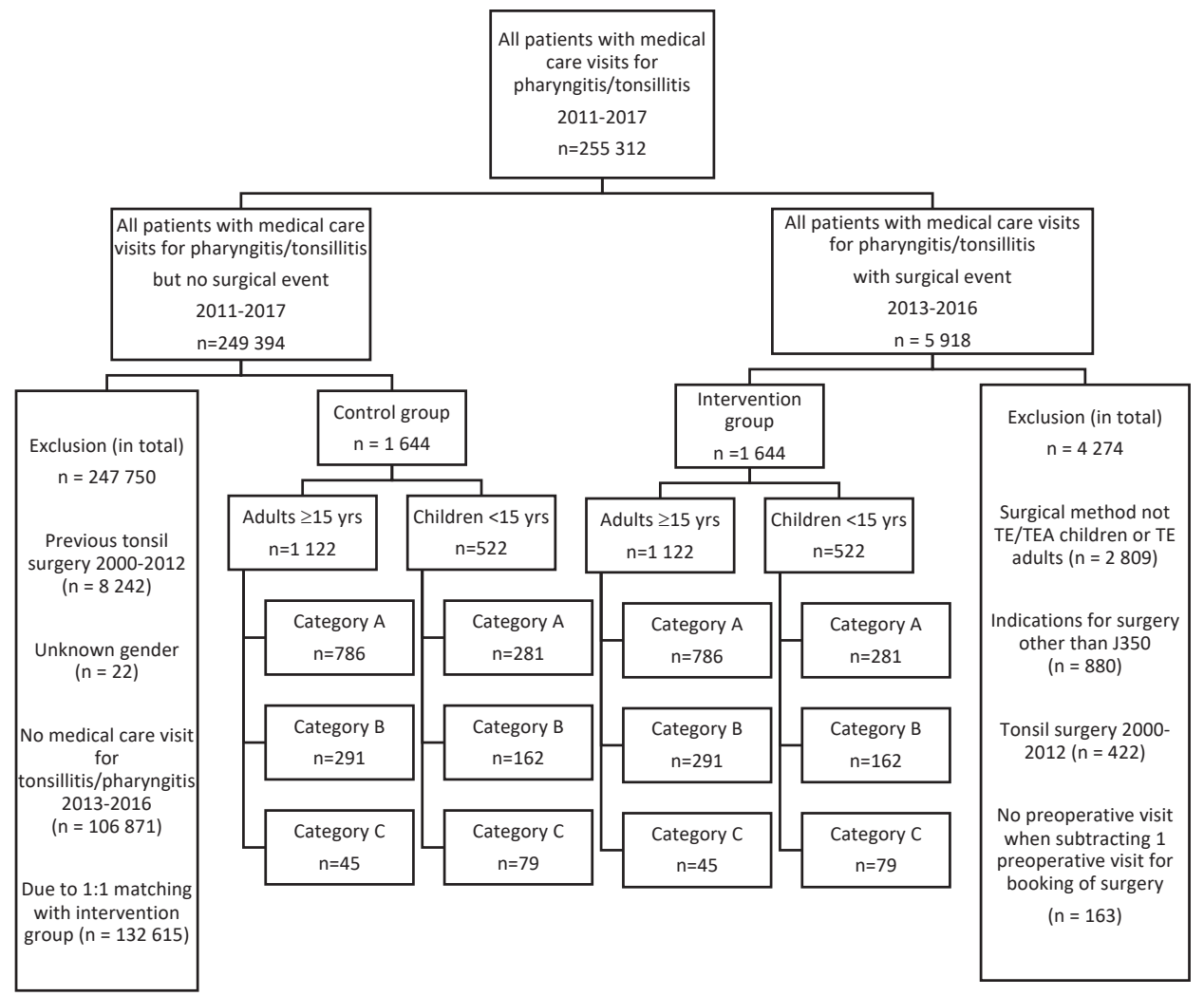

Qualifying ICD codes for medical care visit for pharyngitis or tonsillitis

J02 Acute pharyngitis

J020 Streptococcal pharyngitis

J028 Acute pharyngitis, other microorganisms

J029 Acute pharyngitis unspecified
J03 Acute tonsillitis

J030 Streptococcal tonsillitis

J038 Acute tonsillitis, other microorganisms

J039 Acute tonsillitis unspecified

J350 Chronic tonsillitis

\section{Paper II}

This is an observational retrospective cohort study investigating readmission rates for haemorrhage, reoperation rates for haemorrhage and risk factors for readmission/reoperation for haemorrhage in a national population (Sweden) over 27 years. All tonsil surgeries registered in the NPR from 1987 to 2013 were identified, including 
tonsillectomies \pm adenoidectomies and tonsillotomies \pm adenoidectomies. Surgeries related to malignant disease, lymphoma or congenital abnormalities were excluded. For all identified surgical events, data on gender, age, date of surgery, indication, type of surgery, level of care, length of stay for inpatient surgery, readmission (date and indication) and reoperation for haemorrhage were collected. Patients were divided into four indication-groups based on ICD-IO codes for the surgical event, infection, obstruction, infection and obstruction (both indications) and other indications. Haemorrhage after surgery was defined as readmission to the hospital with an ICD-IO code suggesting bleeding from the head and neck site within 3I days of surgery. Reoperation for haemorrhage was defined as all events of return to the surgical theatre in patients readmitted for haemorrhage. Data analyses were performed on the complete cohort (1987-2013) and longitudinally by year.

Figure 3 Flow-chart paper II

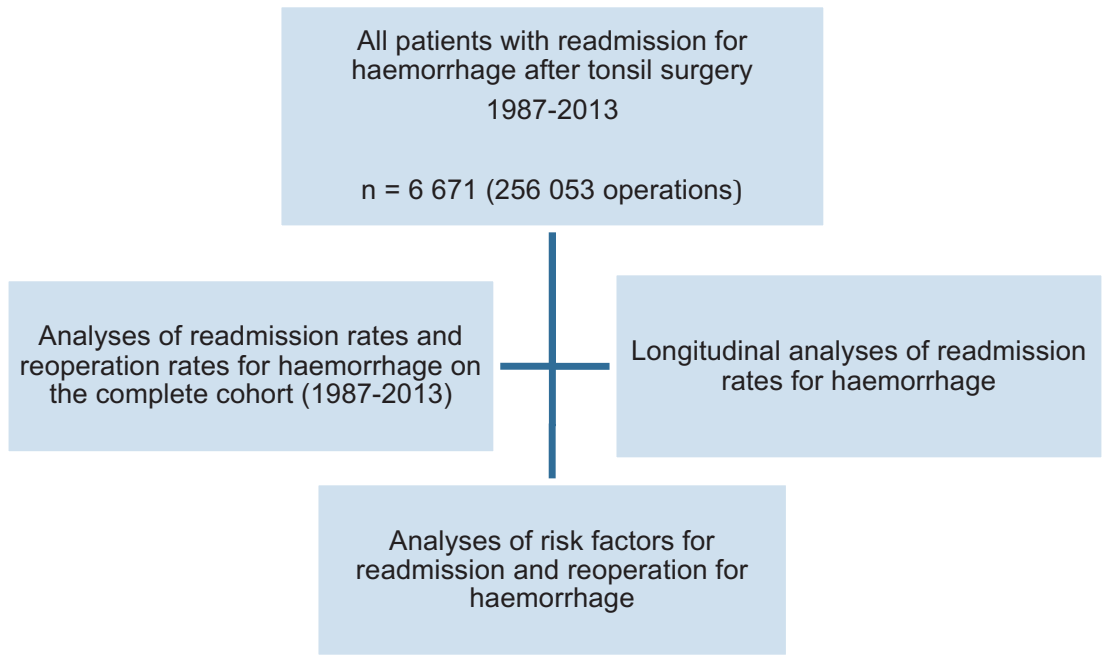

ICD10 codes defining haemorrhage (1997-2013)

T810, T811, T812, T817, R040, R041, R042, R048, R049, R571, R589, S015, S019, S090, S118, S119, S150, S157, S158, S159, D629

ICD9 codes defining haemorrhage (1987-1997)

998A, 998B, 998C, 998D, 784H, 784W, 785F, 459A, 285B 
The primary outcomes were rates of readmission for haemorrhage related to age, gender, indication, type or surgery, level of care and changes in rates over time. Secondary outcomes were rates of reoperation for haemorrhage and risk factors for readmission/reoperation for haemorrhage.

\section{Paper III}

The design of this study was an observational retrospective cohort study. All tonsil surgeries performed in Sweden 2004-20II were identified in the NPR with a search based on the NOMESCO surgical $\operatorname{codes}^{108}$ for tonsil operations including tonsillectomies and tonsillotomies with or without adenoidectomies. All surgeries related to malignant disease or lymphomas were excluded. All identified individuals were subsequently matched with all deaths registered within 30 days of the surgical event in the CDR. The matching was based on the unique personal identity number available for all Swedish citizens. Deaths not related to the surgical events were excluded. A detailed presentation of the fatal events was made based on the information retrieved from the post mortem case investigations through the NBHW.

The primary outcome of the study was the mortality rate after tonsil surgery performed on benign indications in a national population. The secondary outcome was cause of death.

\section{Paper IV}

This is a retrospective cohort study based on data from the NPR and the NTSRS. Data on the number of tonsil surgeries and admissions for haemorrhage were retrieved from both registers for the time period 20092017. In the NPR, surgical events were defined by NOMESCO $\operatorname{codes}^{108}$ for tonsillectomy (EMBIo), adenotonsillectomy (EMB20), tonsillotomy (EMBI5 or EMB99) or adenotonsillotomy (EMBI5+EMB30 or EMB99+EMB30). Surgeries for non-benign indications were excluded, and a maximum of one surgical event per 30-days was allowed to avoid duplicate registrations and inclusion of acute reoperations in the dataset. Admission for haemorrhage was defined as an admission to the hospital between postoperative days I and 30, with an ICD-IO code suggesting bleeding from the head and neck site. 
In the NTSRS, the surgical method for all registered surgeries is reported by the operating surgeon, while patients report on admission for haemorrhage by responding to a questionnaire sent out 30 days after surgery. The mean response rate to the questionnaire was 54.I\% during the 9-year period of the study.

First, data on surgical events present in each register were matched, meaning that registrations for the same surgical events were identified in both registers. A maximum difference of 7 days in surgical dates was accepted to count the events as a match. Subsequently, all surgical events present in one or both of the registers were combined into a merged cohort, which constituted all known tonsil surgeries in Sweden. The same procedure was performed for admission events for haemorrhage, but in addition combinations of a surgical events registered in one register with data on admission for haemorrhage in the other were also included.

The primary outcome in the study was agreement between the registers in reporting of haemorrhage events. The secondary outcome was presentation of the merging process aimed at improving coverage and completeness of the number of surgeries and admissions for haemorrhage when calculating the rate of secondary haemorrhage.

Figure 4 Illustration of the combining of register-data. The merged cohort is represented by the entire coloured area. The matched cohort is represented by the overlapping section of the circles

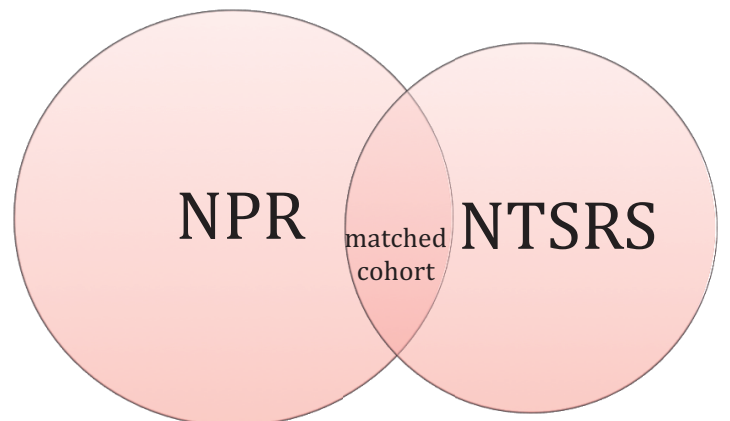

ICD10 codes defining haemorrhage in the NPR (2009-2017)

compared to paper II (crossed out)

T810, T811, T812, T817, R040, R041, R042, R048, R049, R571, R589, S015, S019, S090, S118, S119, S150, S157, S158, S159, D629 


\subsection{Statistics}

\section{Table 9}

Overview of main statistical test/models used in papers I-IV

\begin{tabular}{|c|c|c|c|c|c|}
\hline Description & Statistical methods & $\mathbf{I}$ & II & III & IV \\
\hline $\begin{array}{l}\text { Descriptive analysis } \\
\text { Continuous variables }\end{array}$ & Mean, SD, median, min; max or Q1; Q3 & $x$ & $x$ & $x$ & $x$ \\
\hline Categorical variables & Numbers (n), \% & $x$ & $x$ & & $x$ \\
\hline \multicolumn{6}{|l|}{$\begin{array}{l}\text { For comparison between two } \\
\text { groups: }\end{array}$} \\
\hline Dichotomous variables & $\begin{array}{l}\text { Fisher`s exact test } \\
\text { Continuity adjusted Chi-square test }\end{array}$ & $x$ & $\begin{array}{l}x \\
x\end{array}$ & & $\mathrm{x}$ \\
\hline Continuous variables & Fisher's non-parametric permutation test & $x$ & $x$ & & \\
\hline Ordered categorical variables & Mantel-Haenszel chi-square test & $x$ & & & $x$ \\
\hline Non-ordered categorical var. & Pearson chi-square test & $x$ & & & \\
\hline $\begin{array}{l}\text { Analysis of admission rates } \\
\text { for haemorrhage }\end{array}$ & McNemar`s test & & & & $x$ \\
\hline $\begin{array}{l}\text { Analysis of change within } \\
\text { groups }\end{array}$ & $\begin{array}{l}\text { Fisher's non-parametric permutation test } \\
\text { for paired observations }\end{array}$ & $x$ & & & \\
\hline $\begin{array}{l}\text { Analysis of the relationship } \\
\text { between haemorrhage rates } \\
\text { in NPR and NTSRS }\end{array}$ & Linear regression model & & & & $x$ \\
\hline $\begin{array}{l}\text { Cross sectional correlation } \\
\text { analysis }\end{array}$ & Spearman`s correlation coefficient & & $x$ & & \\
\hline $\begin{array}{l}\text { Estimate adjusted risk ratio } \\
(\mathrm{RR}) \text { with } 95 \% \mathrm{Cl} \text { interval }\end{array}$ & $\begin{array}{l}\text { Generalized linear model with binominal } \\
\text { distribution for the dependent variable, } \\
\text { and log-link function }\end{array}$ & & & & $x$ \\
\hline Analysis of risk factors & Univariable logistic regression analysis & & $x$ & & \\
\hline $\begin{array}{l}\text { Selection of independent risk } \\
\text { factors }\end{array}$ & $\begin{array}{l}\text { Stepwise multivariable logistic } \\
\text { regression }\end{array}$ & & $x$ & & \\
\hline $\begin{array}{l}\text { Incidence of medical care } \\
\text { visits for pharyngitis/tonsillitis }\end{array}$ & $\begin{array}{l}\text { Rate ratio, relative rate reduction and } \\
\text { number needed to treat (NNT) }\end{array}$ & $x$ & & & \\
\hline $\begin{array}{l}\text { Confidence intervals for } \\
\text { continuous variables }\end{array}$ & Bootstrapping & $x$ & & & \\
\hline Test of proportions & Binominal test & & $x$ & & \\
\hline $\begin{array}{l}\text { Analysis of agreement } \\
\text { between registers }\end{array}$ & Cohen`s kappa & & & & $x$ \\
\hline
\end{tabular}


All the statistical analyses were performed by the authors in close collaboration with professional Statisticians.

\section{Paper I}

Change in the yearly mean medical care visit rates after (adeno)tonsillectomy, and the comparison of the change in visit rates between the surgical and non-surgical groups constituted the primary analyses in paper I. In these analyses, tested with Fisher`s non-parametric permutation test, patients contributed their maximum duration of followup years.

For testing differences between the intervention (surgery) and control groups (no surgery) according to the variables listed under general characteristics (results table Io), the choice of statistical test depended on the type of data (table 9). The aim of the matching procedure was to create control groups identical to the intervention groups in all aspects except the intervention; hence, a p-value of I was the ideal. Fisher's nonparametric permutation test was chosen for the continuous variables mean age at surgery and average number of medical care visits in the 2year period prior to surgery/no surgery. The Mantel-Haenszel chi-square test was used for the ordered categorical variables age group, number of medical care visits in the 2 years prior to surgery/no surgery, category and follow-up (number of whole years of follow up). Differences between gender distributions in groups were tested with Fisher's exact test for dichotomous variables. Differences in the distribution of health care providers for the medical care visits were tested with Pearson chisquare test for non-ordered categorical variables.

The subgroup analyses performed for children and adults, the different categories based on the number of preoperative medical care visits, and for the year of follow-up, were presented separately in a forest plot. Absolute rates were given per Ioo person years, and the rate ratios, relative rate reductions and numbers needed to treat (NNTs) were presented to enable comparisons of the effectiveness of the surgical intervention in the different subgroups. P-values were given for the calculations of the rate ratios. NNT was defined as the number of patients needed to undergo surgery to save one medical care visit for tonsillitis or pharyngitis. 
To determine if adenoid surgery affected the reported outcome in children, sensitivity analyses were performed. The different variables were tested with the chosen statistical tests presented above, depending on the nature of the variable (continuous/ordered categorical/non-ordered categorical/dichotomous), comparing children who underwent tonsillectomy with children who underwent adenotonsillectomy. No statistically significant differences between the surgical methods were observed and the groups were therefore pooled for the subsequent analyses.

To investigate whether loss to follow-up, caused by the set time restriction of the intervention-period (2013-20I6) in relation to the available data (until 3I Dec 20I7), affected the composition of the intervention and control groups the second and third year of follow-up, dropouts were compared to the remaining patients in the study. In addition, the remaining patients in the intervention and control groups year 2 and 3 were compared. Relevant variables were tested as described above.

\section{Paper II}

Readmission rates for haemorrhage (secondary haemorrhage) were calculated as all readmission events for haemorrhage divided by all operations for each year and the entire period (1987-2013). Reoperation rates were correspondingly calculated as all patients with a return to theatre (RTT) following readmission for haemorrhage divided by all surgeries. Data were presented as the mean haemorrhage rates and reoperation rates for the period $1987-2013$ with line charts showing the trends in rates over time.

Longitudinal analyses were performed with calendar year used as a continuous variable. Trends in proportions were tested with logistic regression and included trends in the number of tonsil surgeries performed and the distribution of indications, type of surgery and level of care. Correspondingly, trends in haemorrhage rates for the same variables were tested with the same method, logistic regression. Trends in mean age at surgery were tested with Spearman's rank correlation test (correlation between counts and calendar year). Differences in proportions between two time periods for both number of surgeries and overall haemorrhage and reoperation rates, including subgroup analyses for the variables indication group, type of surgery and level of care, were 
tested with Fisher`s Exact test. A continuity adjusted chi-square test was used to test the proportion of readmissions for haemorrhage out of all readmissions, and the 5-year period from 1987-I99I was compared to the 5 -year period from 2009-2013. A binominal test was used to test the claim that outpatient care became the most prevalent level of care after $20 \mathrm{IO}$ (testing observed proportions against predefined proportions $(50 \%)$ ). Trends in the continuous variable length of stay (LOS) were tested with Fisher's non-parametric permutation test.

A univariable logistic regression was performed to identify tentative risk factors for both readmission and reoperation for haemorrhage. Statistically significant risk factors were then entered into a stepwise forward multivariable regression model to identify independent risk factors, and the results were presented as unadjusted and adjusted odds ratios (ORs) with 95\% confidence intervals (CIs). Calculations of univariable relative risks with $95 \%$ CIs and area under ROC curves were not presented in the published article, but these complementary analyses have been performed and are presented in the results section.

\section{Paper III}

In this paper, the objective was to present the incidence rate of mortality after tonsil surgery in Sweden. The incidence rate was calculated as the number of fatal events related to the surgery performed divided by the total number of surgeries registered in the NPR 2004-20II and was reported with a $95 \%$ confidence interval. Case reports of the two fatal events were presented.

\section{Paper IV}

The number of surgeries identified in the NPR and the NTSRS were presented separately for each register and combined into a matched cohort (surgeries present in both registers) and a merged cohort (surgeries present in either register). Coverage was defined as the number of tonsil surgeries found in each register divided by all identified tonsil surgeries (merged cohort). Completeness was defined as the number of reporting units in each register divided by all reporting units (to any register).

Admissions for haemorrhage were presented as unique admissions found in each register, a matched cohort of admissions for haemorrhage with the corresponding surgeries found in both registers, and a merged cohort 
of all known admissions for haemorrhage. Unique admissions found by the merging process were also presented separately. Admission rates for haemorrhage were calculated for each register separate and for the merged cohort by dividing number of identified admissions for haemorrhage by the number of identified surgeries. When calculating the haemorrhage rates in the NTSRS and the merged cohort, only surgeries where the patients had responded yes or no to the 30-day questionnaire were included.

The relationships between the calculated haemorrhage rates per year (2009-20I7) in the two registers (9 observations) were tested with a linear regression model. Equations for the regression lines as well as standarddeviations for the residuals (Root MSE) and $\mathrm{R}^{2}$ were presented.

Inter-rater reliability or agreement between reported haemorrhage events in the registers was determined with percent agreement and Cohen's kappa statistic. These calculations were performed on a matched cohort of patients with surgeries and information on admission for haemorrhage available in both registers (non-responders to the 30-day questionnaire were not included).

McNemar's test was used to compare the admission rates in the registers (paired categorical variables). For testing trends in unadjusted (for known risk factors for haemorrhage) haemorrhage rates over time in the merged cohort, the Mantel-Haenszel chi-square test was used, while Fisher's exact test was chosen to test the difference in haemorrhage rates between 2009 and 2017 (difference in proportions).

In the subgroup analysis (haemorrhage rates for different surgical methods in the merged cohort), estimates of relative risks (RRs) with $95 \%$ confidence intervals for admission for haemorrhage were calculated with a generalized linear model with binominal distribution for the dependent variable, and a log-link function.

Fisher's exact test was used to test if admission rates for haemorrhage in the responders and non-responders to the 30-day questionnaire in NTSRS differed through comparisons with the NPR. 


\subsection{Ethical considerations}

All studies were conducted in accordance with the Declaration of Helsinki and were approved by the Regional Ethical Review Board at the University of Gothenburg (Dnr. 257-I4 (papers I, II, IV) and Dnr. 885-I2 (paper III)).

We have strived to report all relevant findings in the papers and in this thesis in an honest, accurate and transparent way. None of the authors behind the papers have declared any conflicts of interest.

The studies in this thesis were supported by grants from:

- The Foundation Acta Oto-Laryngologica

- The Gothenburg Society of Medicine (GLS 78580I)

- The regional ALF project funding (Region Västra Götaland and Gothenburg University) for clinically oriented medical research projects (VGFOUREG-39I65I) 


\section{Results}

\subsection{Paper I}

3288 patients met inclusion and exclusion criteria and 1644 patients (522 children and 1122 adults) were included in the intervention and control groups, respectively.

The general characteristics of the study population is presented in table 10. As a result of the matching procedure, no significant differences were observed between the intervention- and control groups regarding the matching variables: age group, gender and number of medical care visits before surgery/no surgery $(\mathrm{p}=1.00)$. Visits to a primary care physician were significantly more frequent in the control groups, but both groups had overall most visits in primary care. The gender distribution was skewed towards females in adults $(68.6 \%)$ and was close to equal in children. Three-quarters of the children were $\geq 5$ years of age, while most adults were younger than 40 years of age. Regarding the distribution of medical care visits within each category, $84.8 \%$ of the children and $96.0 \%$ of the adults had $<7$ medical care visits in the observation period before intervention/no intervention, and $53.8 \%$ of the children and $70.1 \%$ of the adults had less than four visits. The mean follow-up time was 2.39 vs 2.52 years for the intervention vs control groups in children and, correspondingly, 2.38 vs 2.44 years in adults. Significantly higher number of patients in the control group for children had three years of follow up $(\mathrm{p}=0.0008)$, otherwise no statistically significant differences were seen in length (years) of follow-up. 
Table 10

General characteristics of the study population

\begin{tabular}{|c|c|c|c|c|}
\hline & \multicolumn{2}{|c|}{ Children (TE or TEA) } & \multicolumn{2}{|c|}{ Adults (TE) } \\
\hline & $\begin{array}{c}\text { Intervention } \\
\text { Group } \\
(n=522)\end{array}$ & $\begin{array}{l}\text { Control Group } \\
\qquad(n=522)\end{array}$ & $\begin{array}{c}\text { Intervention } \\
\text { Group } \\
(n=1122)\end{array}$ & $\begin{array}{l}\text { Control Group } \\
\quad(n=1122)\end{array}$ \\
\hline \multicolumn{5}{|l|}{ Age } \\
\hline $0-4$ & $137(26.2 \%)$ & $137(26.2 \%)$ & & \\
\hline $5-6$ & $126(24.1 \%)$ & $126(24.1 \%)$ & & \\
\hline $7-14$ & $259(49.6 \%)$ & $259(49.6 \%)$ & & \\
\hline $15-39$ & & & $1046(93.2 \%)$ & $1046(93.2 \%)$ \\
\hline $40-$ & & & $76(6.8 \%)$ & $76(6.8 \%)$ \\
\hline \multirow[t]{3}{*}{ Age at surgery* } & $7.75(3.49)$ & $7.26(3.36)$ & $25.1(8.7)$ & $28.2(9.7)$ \\
\hline & $6.98(1.70 ; 14.99)$ & $6.97(0.53 ; 14.99)$ & $22.1(15.0 ; 78.2)$ & $26.9(15.0 ; 88.7)$ \\
\hline & $(7.45 ; 8.05)$ & $(6.97 ; 7.55)$ & $(24.6 ; 25.6)$ & $(27.7 ; 28.8)$ \\
\hline \multicolumn{5}{|l|}{ Gender } \\
\hline male & $256(49.0 \%)$ & $256(49.0 \%)$ & $352(31.4 \%)$ & $352(31.4 \%)$ \\
\hline Female & $266(51.0 \%)$ & $266(51.0 \%)$ & $770(68.6 \%)$ & $770(68.6 \%)$ \\
\hline \multicolumn{5}{|l|}{ Medical care provider* } \\
\hline Primary care physician & $1624(80.8 \%)$ & $1841(93.5 \%)$ & $2593(79.8 \%)$ & $3004(93.5 \%)$ \\
\hline Specialist (public care) & $316(15.7 \%)$ & $105(5.3 \%)$ & $530(16.3 \%)$ & $178(5.5 \%)$ \\
\hline Specialist (private care) & $71(3.5 \%)$ & $22(1.1 \%)$ & $125(3.8 \%)$ & $32(1.0 \%)$ \\
\hline \multicolumn{5}{|l|}{$\begin{array}{l}\text { Category (visits before } \\
\text { surgery/no surgery) }\end{array}$} \\
\hline A: 1-3 visits & $281(53.8 \%)$ & $281(53.8 \%)$ & $786(70.1 \%)$ & $786(70.1 \%)$ \\
\hline B: 4-6 visits & $162(31.0 \%)$ & $162(31.0 \%)$ & $291(25.9 \%)$ & $291(25.9 \%)$ \\
\hline C: 7+ visits & $79(15.1 \%)$ & $79(15.1 \%)$ & $45(4.0 \%)$ & $45(4.0 \%)$ \\
\hline \multicolumn{5}{|l|}{ Follow-up } \\
\hline 1 year follow-up & $522(100 \%)$ & $522(100 \%)$ & $1122(100 \%)$ & $1122(100 \%)$ \\
\hline 2 years follow-up & $419(80.3 \%)$ & $437(83.7 \%)$ & $892(79.5 \%)$ & $922(82.2 \%)$ \\
\hline 3 years follow-up* & $304(58.2 \%)$ & $357(68.4 \%)$ & $659(58.7 \%)$ & $697(62.1 \%)$ \\
\hline
\end{tabular}

* Medical care provider and the continuous variable age at surgery were statistical different between groups, $p<0.0001$. Significantly higher number of control-group children had 3 years of follow up. Age (group), gender and category (visits before surgery/no surgery had $p=1.0$. 
There was a significant decrease in the yearly mean medical care visit rates in both children, (-1.80 (-1.90 to -1.69)), and adults, (-1.30 (-1.36 to -1.24)), after (adeno)tonsillectomy. A significant decrease was also observed in patients who did not undergo surgery, -1.51 (-1.61 to -1.41$)$ in children vs $-1.18(-1.24$ to -1.13$)$ in adults. There was a greater decrease in visit rates in the surgical group compared to patients who did not undergo surgery, regardless of age. The mean difference for the change in rates between the intervention and control group was $-0.283(-0.436$ to -0.135$)$ for children and $-0.111(-0.195$ to -0.028$)$ for adults.

Table 11 The main results from paper I

\begin{tabular}{|c|c|c|c|}
\hline & $\begin{array}{l}\text { intervention } \\
\text { (surgery) }\end{array}$ & $\begin{array}{c}\text { control } \\
\text { (fictive surgery) }\end{array}$ & $\begin{array}{c}\text { differences } \\
\text { (between groups) }\end{array}$ \\
\hline \multicolumn{4}{|l|}{$\begin{array}{c}\text { children (<15 years) } \\
n=522\end{array}$} \\
\hline $\begin{array}{c}\text { yearly rate } \\
\text { of medical care visits } \\
\text { before ( } 2 \text { years) } \\
\text { surgery/fictive surgery }\end{array}$ & $\begin{array}{c}1.93 \\
(1.82 ; 2.04) \\
1.5(0.5 ; 8.5)\end{array}$ & $\begin{array}{c}1.89 \\
(1.79 ; 1.98) \\
1.5(0.5 ; 7)\end{array}$ & $\begin{array}{c}0.041 \\
(-0.107 ; 0.194)\end{array}$ \\
\hline $\begin{array}{c}\text { yearly rate } \\
\text { of medical care visits } \\
\text { after (up to } 3 \text { years) } \\
\text { surgery/fictive surgery }\end{array}$ & $\begin{array}{c}0.129 \\
(0.099 ; 0.165) \\
0(0 ; 4.33)\end{array}$ & $\begin{array}{c}0.371 \\
(0.312 ; 0.433) \\
0(0 ; 7)\end{array}$ & $\begin{array}{c}-0.241 \\
(-0.313 ;-0.174)\end{array}$ \\
\hline $\begin{array}{c}\text { change in rate } \\
\text { before and after } \\
\text { surgery/fictive surgery }\end{array}$ & $\begin{array}{l}-1.80 \\
(-1.90 ;-1.69) \\
-1.5(-7 ; 1) \\
\end{array}$ & $\begin{array}{l}-1.51 \\
(-1.61 ;-1.41) \\
-1.33(-7 ; 4) \\
\end{array}$ & $\begin{array}{c}-0.283 \\
(-0.436 ;-0.135)\end{array}$ \\
\hline $\begin{array}{c}p \text {-value } \\
\text { adults ( } \geq 15 \text { years) } \\
n=1122\end{array}$ & $<0.0001$ & $<0.0001$ & 0.0002 \\
\hline $\begin{array}{c}\text { yearly rate } \\
\text { of medical care visits } \\
\text { before ( } 2 \text { years) } \\
\text { surgery/fictive surgery }\end{array}$ & $\begin{array}{c}1.45 \\
(1.39 ; 1.51) \\
1(0.5 ; 10.5)\end{array}$ & $\begin{array}{l}1.43 \\
(1.38 ; 1.49) \\
1(0.5 ; 7.5)\end{array}$ & $\begin{array}{c}0.015 \\
(-0.064 ; 0.094)\end{array}$ \\
\hline $\begin{array}{c}\text { yearly rate } \\
\text { of medical care visits } \\
\text { after (up to } 3 \text { years) } \\
\text { surgery/fictive surgery }\end{array}$ & $\begin{array}{c}0.152 \\
(0.132 ; 0.173) \\
0(0 ; 3)\end{array}$ & $\begin{array}{c}0.248 \\
(0.213 ; 0.288) \\
0(0 ; 8)\end{array}$ & $\begin{array}{c}-0.096 \\
(-0.141 ;-0.054)\end{array}$ \\
\hline $\begin{array}{c}\text { change in rate } \\
\text { before and after } \\
\text { surgery/fictive surgery }\end{array}$ & $\begin{array}{c}-1.30 \\
(-1.36 ;-1.24) \\
-1(-10.5 ; 1.5) \\
\end{array}$ & $\begin{array}{l}-1.18 \\
(-1.24 ;-1.13) \\
-1(-6.83 ; 6) \\
\end{array}$ & $\begin{array}{c}-0.111 \\
(-0.195 ;-0.028)\end{array}$ \\
\hline$p$-value & $<0.0001$ & $<0.0001$ & 0.0097 \\
\hline
\end{tabular}


The results from the subgroup analyses are condensed into figure 5. The rate ratios demonstrated an effect of surgery for all patients regardless of the number of preoperative medical care visits: however, the results were not statistically significant for all subgroups. Lower numbers needed to treat were observed for patients with $7+$ medical care visits prior to surgery compared to patients with fewer visits, and significantly lower NNTs were observed for the first two years after surgery for children and the first year in adults. No systematic pattern in relative rate reductions was observed across categories or follow-up years.

The dropout analyses showed a significantly higher number of dropouts in the intervention groups and in category A patients in years 2 and 3 and in females in year 2. However, for patients remaining for years 2 and 3, no statistically significant differences were observed between the intervention and control groups for the baseline variables, and the groups were still considered comparable in years 2 and 3 .

Figure 5 Forest plot for the subgroup analyses

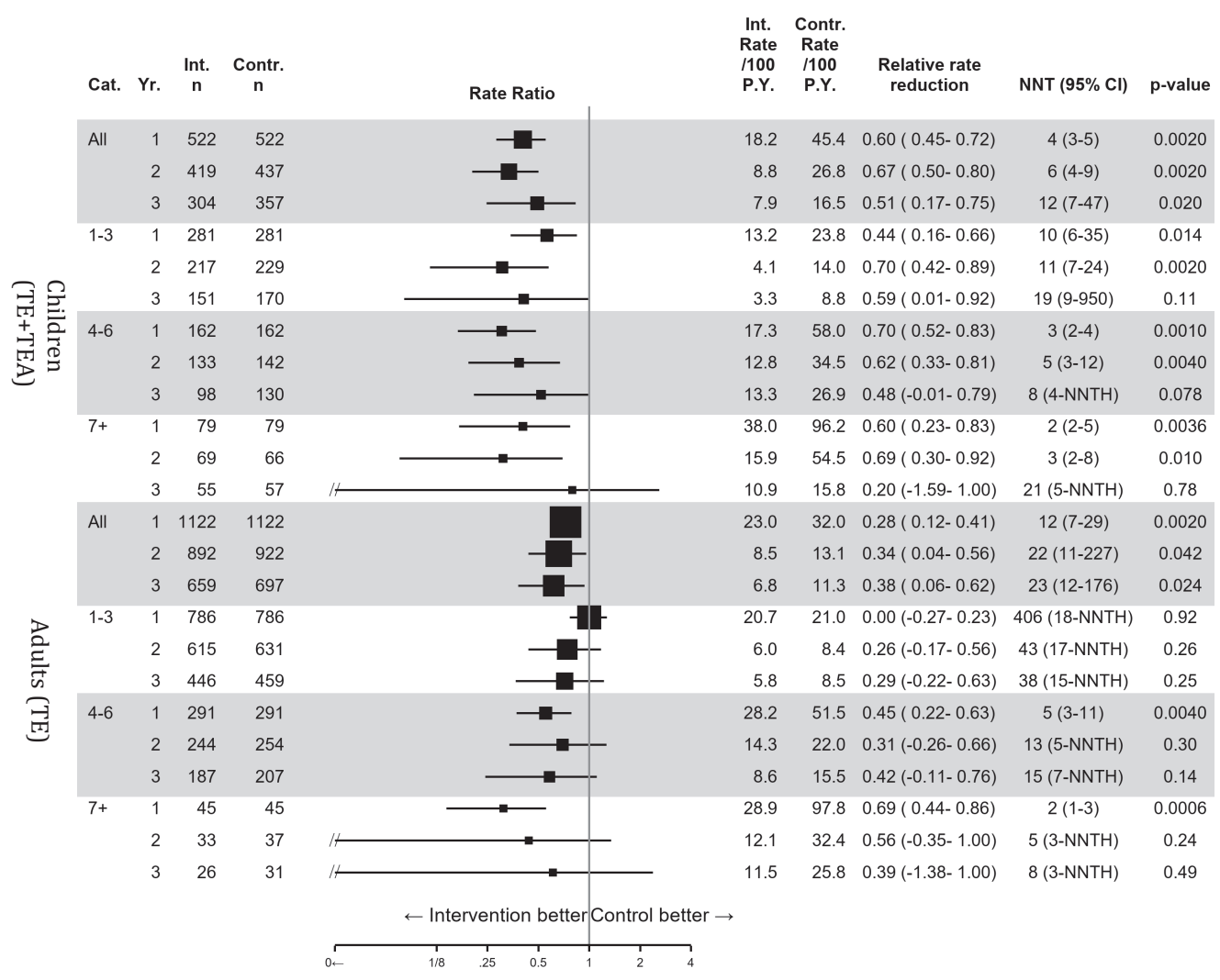




\subsection{Paper II}

Data on 264667 tonsil operations performed from 1987-2013 were retrieved from the NPR, and after exclusion of 8614 due to errors in coding (2 723) and non-benign indications for surgery (5 891), 256053 patients were included in the statistical analysis. The gender distribution was close to equal with a mean age of 15.3 years, while a higher proportion of females and higher mean age was observed in the tonsillectomy group compared to all other surgical methods. Upper airway obstruction was the most prevalent indication $(50.3 \%)$, and tonsillectomy was the most prevalent surgical method (60.4\%). Adenotonsillectomies and tonsillotomies \pm adenoidectomies were mainly performed in children for obstructive disease.

Table 12

General Characteristics of all tonsil operations (benign indications) in Sweden 1987-2013

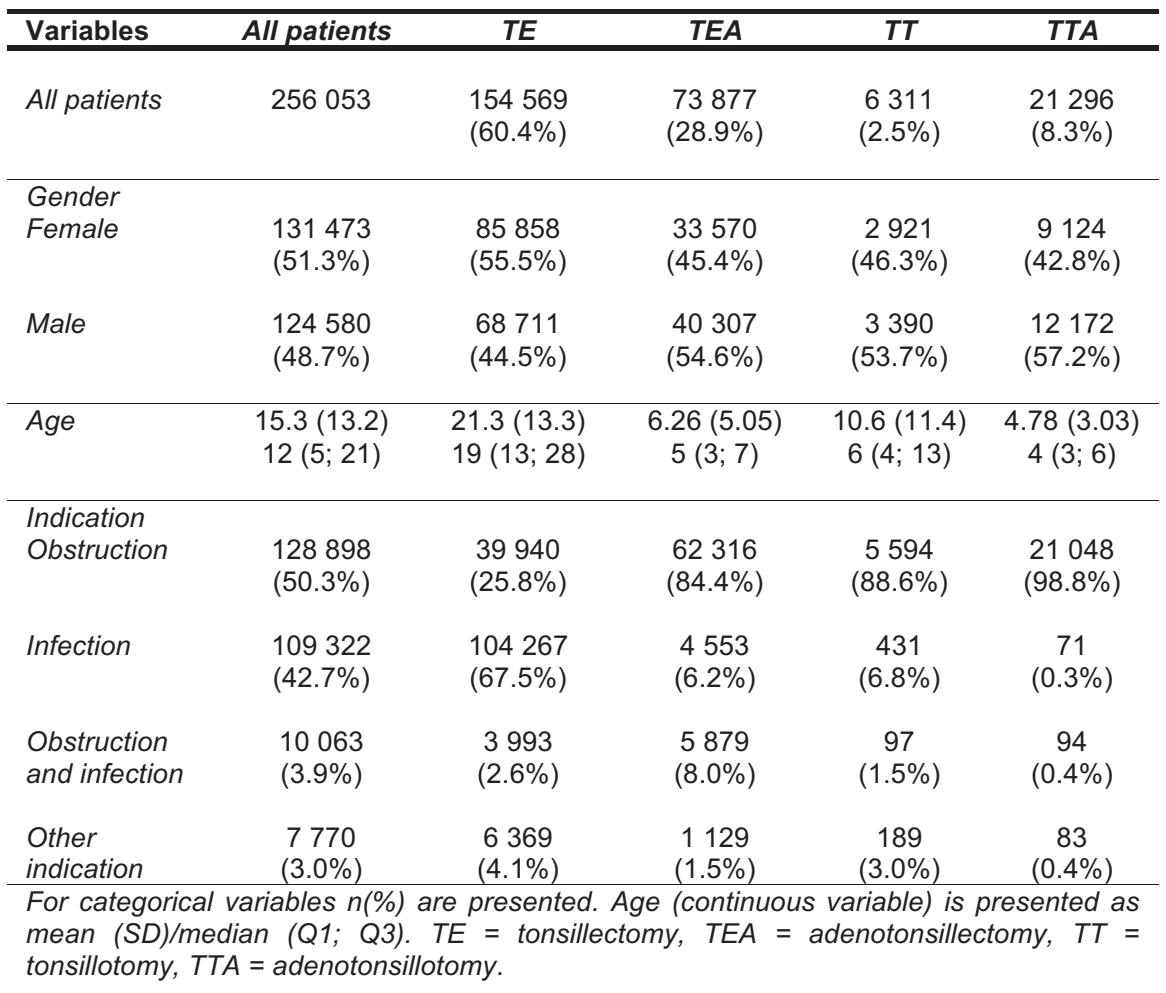


The readmission rate for haemorrhage (1987-2013) was $2.61 \%$ (2.54 to 2.67 ), and the reoperation rate was $0.84 \%$ ( 0.81 to 0.88 ). The longitudinal analyses showed a significant increase in the readmission rate for haemorrhage, from $1.12 \%$ (0.89 to 1.40 ) in 1987 to $4.80 \%$ (4.43 to 5.19) in 2013. Approximately $1 / 3$ of all readmissions for haemorrhage required reoperation; however, this rate increased significantly from $18 \%$ in 1987 to $43 \%$ in 2013 . The increase in readmission rates was most pronounced for adults who underwent tonsillectomy for throat infections, and tonsillectomy had a readmission rate of $9.17 \%$ (8.42 to 9.97) in 2013 while infectious indications had a rate of $9.63 \%$ (8.75 to $10.56 \%)$. Overall readmission rates for outpatient care was higher than for inpatient care, however, after 2010, when outpatient care became the most frequently used care-form, inpatient care had a higher risk of haemorrhage. The proportion of all readmissions caused by haemorrhage increased from $46.9 \%$ in 1987 to $68.4 \%$ in 2013 . The median number of days after surgery for readmission was 6 for the entire period (19872013), 7 in 1987 and 6 in 2013. During the period 1987-2013, 8.3\% of the patients who experiences a readmission for haemorrhage were admitted a second time for haemorrhage and less than $1 \%$ had more than 2 readmissions. Less than $1 \%$ of bleedings occurred after 3 weeks.

Figure 6

Days to readmission for haemorrhage in 1987 and 2013

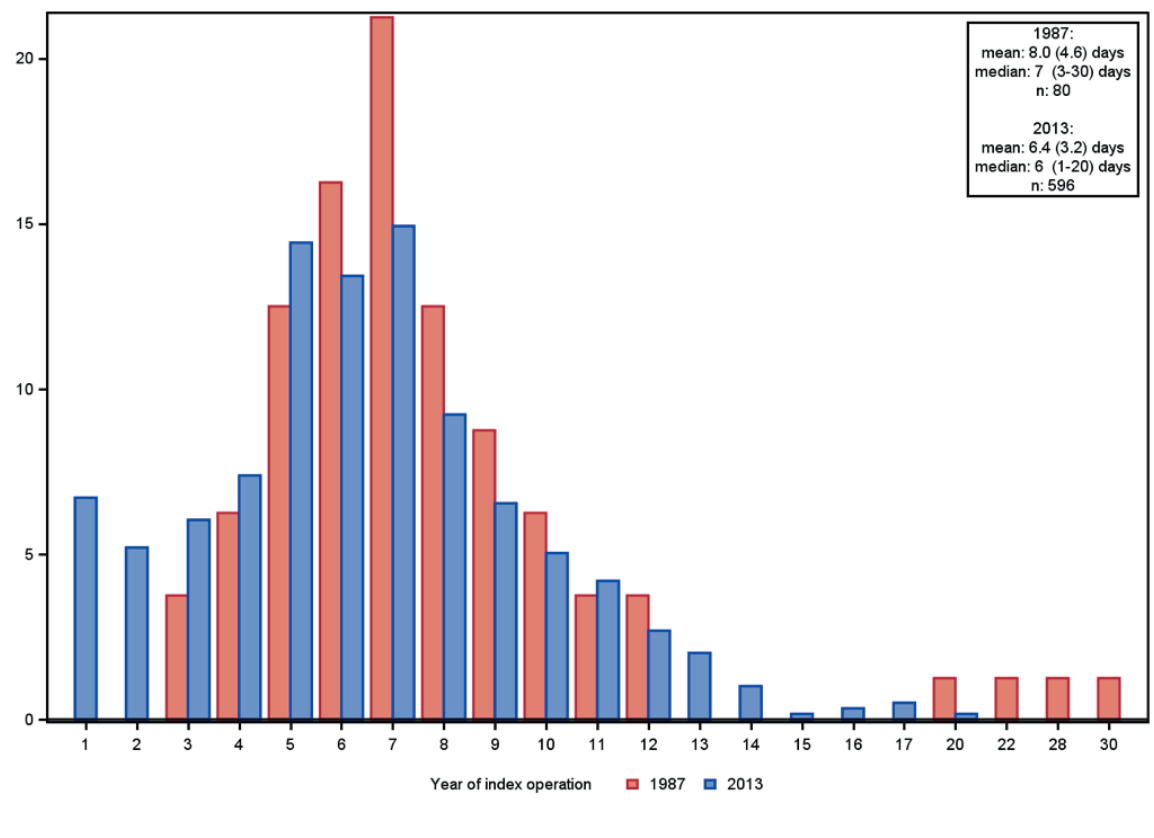


Table 13

Readmission and reoperation rates for haemorrhage (1987-2017)

\begin{tabular}{|c|c|c|c|}
\hline & $\begin{array}{l}\text { Number of } \\
\text { operations }\end{array}$ & $\begin{array}{c}\text { Readmission rate for } \\
\text { haemorrhage }\end{array}$ & $\begin{array}{l}\text { Reoperation rate } \\
\text { for haemorrhage }\end{array}$ \\
\hline All patients & 256053 & $2.61(2.54 ; 2.67)$ & $0.84(0.81 ; 0.88)$ \\
\hline $\begin{array}{l}\text { Gender } \\
\text { Female } \\
\text { Male }\end{array}$ & $\begin{array}{l}131473(51.3 \%) \\
124580(48.7 \%)\end{array}$ & $\begin{array}{l}2.39(2.31 ; 2.48) \\
2.83(2.74 ; 2.92)\end{array}$ & $\begin{array}{l}0.75(0.71 ; 0.80) \\
0.94(0.88 ; 0.99)\end{array}$ \\
\hline $\begin{array}{l}\text { Age } \\
<18 \text { years } \\
\geq 18 \text { years }\end{array}$ & $\begin{array}{r}166053(64.9 \%) \\
90000(35.1 \%)\end{array}$ & $\begin{array}{l}1.54(1.48 ; 1.60) \\
4.57(4.43 ; 4.70)\end{array}$ & $\begin{array}{l}0.47(0.44 ; 0.51) \\
1.53(1.45 ; 1.61)\end{array}$ \\
\hline $\begin{array}{l}\text { Type of surgery } \\
\text { Tonsillectomy } \\
\text { Adenotonsillectomy } \\
\text { Tonsillotomy } \\
\text { Adenotonsillotomy }\end{array}$ & $\begin{array}{r}154569(60.4 \%) \\
73877(28.9 \%) \\
6311(2.5 \%) \\
21296(8.3 \%)\end{array}$ & $\begin{array}{l}3.59(3.50 ; 3.69) \\
1.23(1.15 ; 1.31) \\
1.58(1.29 ; 1.92) \\
0.52(0.42 ; 0.62)\end{array}$ & $\begin{array}{l}1.18(1.13 ; 1.24) \\
0.37(0.32 ; 0.41) \\
0.59(0.41 ; 0.81) \\
0.12(0.08 ; 0.17)\end{array}$ \\
\hline $\begin{array}{l}\text { Indication } \\
\text { Obstruction } \\
\text { Infection } \\
\text { Obstruction and } \\
\text { infection } \\
\text { Other indication }\end{array}$ & $\begin{array}{r}128898(50.3 \%) \\
109322(42.7 \%) \\
10063(3.9 \%)\end{array}$ & $\begin{array}{l}1.54(1.48 ; 1.61) \\
3.84(3.73 ; 3.95) \\
3.43(3.08 ; 3.80) \\
1.80(1.52 ; 2.12)\end{array}$ & $\begin{array}{l}0.46(0.43 ; 0.50) \\
1.28(1.21 ; 1.34) \\
1.24(1.04 ; 1.48) \\
0.58(0.42 ; 0.77)\end{array}$ \\
\hline $\begin{array}{l}\text { Level of care* } \\
\text { Inpatient } \\
\text { Outpatient }\end{array}$ & $\begin{array}{r}103194(68.9 \%) \\
46683(31.1 \%) \\
\end{array}$ & $\begin{array}{l}3.52(3.41 ; 3.64) \\
3.94(3.76 ; 4.12)\end{array}$ & $\begin{array}{l}1.12(1.05 ; 1.18) \\
1.63(1.52 ; 1.75)\end{array}$ \\
\hline
\end{tabular}

Figure 7

Readmission rates for haemorrhage (1987-2017) with 95\% confidence intervals including data on reoperation rates for haemorrhage and readmission rates all causes

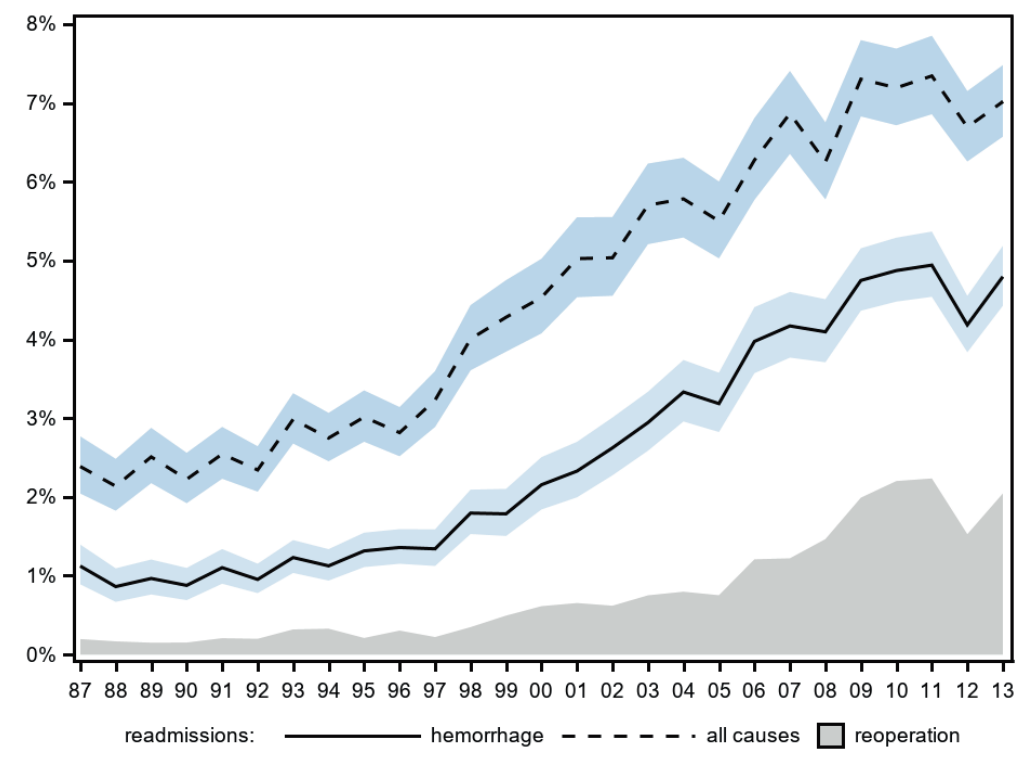


The univariable regression identified male gender, increasing age, tonsillectomy, infection or infection and obstruction as the indication for surgery, outpatient surgery, length of stay (short) and a more recent year for the index operation as risk factors for readmission and reoperation for haemorrhage. The risk factors were entered stepwise into a multivariable regression model, and all risk factors except level of care remained statistically significant with comparable values for the odds ratios. However, when adjusting for age in the multivariable model adenotonsillectomy had higher odds of haemorrhage compared to tonsillotomy. The risk factors for reoperation were the same as for readmission with slightly different values and larger confidence intervals. The AUC for the multivariable model was 0.75 for readmission and 0.80 for reoperation. As shown in table 14, the calculated relative risks for the univariable model were very similar to the odds ratios, as expected when the outcome is rare $(<10 \%)$.

Table 14

Risk factors for readmission for haemorrhage

\begin{tabular}{|c|c|c|c|}
\hline & $\begin{array}{c}\text { OR } \\
\text { Univariable } \\
\text { model }\end{array}$ & $\begin{array}{c}R R \\
\text { Univariable } \\
\text { model }\end{array}$ & $\begin{array}{c}\text { OR } \\
\text { Multivariable } \\
\text { model }\end{array}$ \\
\hline Gender: Male vs female & $1.19(1.13 ; 1.25)$ & $1.18(1.13 ; 1.24)$ & $1.30(1.24 ; 1.37)$ \\
\hline Age (per 10 years) & $1.31(1.29 ; 1.33)$ & $1.29(1.27 ; 1.31)$ & $1.32(1.30 ; 1.35)$ \\
\hline $\begin{array}{l}\text { Type of surgery } \\
\text { Tonsillectomy } \\
\text { Adenotonsillectomy } \\
\text { Tonsillotomy } \\
\text { Adenotonsillotomy }\end{array}$ & $\begin{array}{l}3.34(3.13 ; 3.56) \\
0.38(0.36 ; 0.41) \\
0.60(0.49 ; 0.73) \\
0.18(0.15 ; 0.22)\end{array}$ & $\begin{array}{l}3.25(3.05 ; 3.47) \\
0.39(0.36 ; 0.42) \\
0.60(0.50 ; 0.73) \\
0.18(0.15 ; 0.22)\end{array}$ & $\begin{array}{l}3.31(3.07 ; 3.57) \\
0.66(0.61 ; 0.71) \\
0.41(0.34 ; 0.50) \\
0.13(0.10 ; 0.15)\end{array}$ \\
\hline $\begin{array}{l}\text { Indication } \\
\text { Obstruction } \\
\text { Infection } \\
\text { Obstruction and infection } \\
\text { Other indications }\end{array}$ & $\begin{array}{l}0.41(0.39 ; 0.43) \\
2.33(2.21 ; 2.45) \\
1.35(1.21 ; 1.50) \\
0.68(0.57 ; 0.80)\end{array}$ & $\begin{array}{l}0.42(0.40 ; 0.44) \\
2.28(2.17 ; 2.39) \\
1.33(1.20 ; 1.48) \\
0.69(0.58 ; 0.81)\end{array}$ & $\begin{array}{l}0.44(0.42 ; 0.47) \\
2.20(2.08 ; 2.33) \\
1.19(1.07 ; 1.34) \\
0.56(0.47 ; 0.67)\end{array}$ \\
\hline Length of stay (per day) & $0.77(0.76 ; 0.79)$ & $0.78(0.76 ; 0.79)$ & $0.96(0.94 ; 0.98)$ \\
\hline $\begin{array}{l}\text { Level of care* } \\
\text { Outpatient vs inpatient }\end{array}$ & $1.12(1.06 ; 1.19)$ & $1.12(1.06 ; 1.18)$ & \\
\hline Year of index operation (per year) & $1.08(1.08 ; 1.08)$ & $1.08(1.07 ; 1.08)$ & $1.09(1.09 ; 1.09)$ \\
\hline
\end{tabular}




\subsection{Paper III}

The search in the NPR from 2004 to 2011 identified 82527 tonsil surgeries performed on benign indications. The matching between the NPR and the CDR identified six fatal events after tonsil surgery; four were excluded due to a cause of death unrelated to the surgery performed.

The mortality rate after tonsil surgery in Sweden was calculated as follows:

Mortality rate $=\frac{\text { Number of deaths after tonsil surgery }}{\text { Total number of surgeries }}=\frac{1}{41263}=$ $0.0024235 \%$ with $95 \%$ confidence interval ( 0.0000614 to 0.0135020$)$, corresponding to a rate of $1 / 41263$ (1/7406 to $1 / 1628664)$.

Table 15

Case reports of the fatal events

Case I

4 years

male

Hypertrophy of the tonsils (J351)

Indication for surgery

Surgical method

Surgical technique

Haemostasis

Postoperative

analgesics

Time of death

Cause of death

(autopsy)
Tonsillectomy + adenoidectomy (EMB20)

Adenoids: Not specified Tonsils: Coblation Not specified

Paracetamol Ibuprofen 3 days after surgery Airway obstruction due to bleeding and hemodynamic failure
Case II

2 years
male

Hypertrophy of tonsils with hypertrophy of adenoids (J353) Tonsillotomy + adenoidectomy (EMB99+EMB30) Adenoids: Cold steel Tonsils: Coblation Compression bipolar diathermy Paracetamol Ibuprofen 6 days after surgery 


\subsection{Paper IV}

Combining data on the number of registered tonsil surgeries from the NPR and the NTSRS gave a total population of 117685 tonsil surgeries performed in Sweden from 2009-2017 on benign indications, with a mean of 13076 surgeries performed annually. In building the merged cohort, $24.6 \%$ of the surgeries were only identified in the NPR, while $5.4 \%$ were only registered in the NTSRS. The NPR had a mean coverage of $94.6 \%$ and a completeness of $97.8 \%$. The NTSRS had a mean coverage of $75.4 \%$ and a completeness of $82.9 \%$.

The admission rate for haemorrhage was calculated for each register separately and for the merged cohort. The rate was $4.1 \%$ in the NPR, $5.1 \%$ in the NTSRS and $4.5 \%$ in the merged cohort, as illustrated in figure 8. A significant decrease in haemorrhage rates in the merged cohort was observed over time ( $p<0.0001$ ), from $5.0 \%$ in 2009 to $3.2 \%$ in 2017.

Figure 8

Admission rates for haemorrhage in the NPR, the NTSRS and the merged cohort 2009-2017

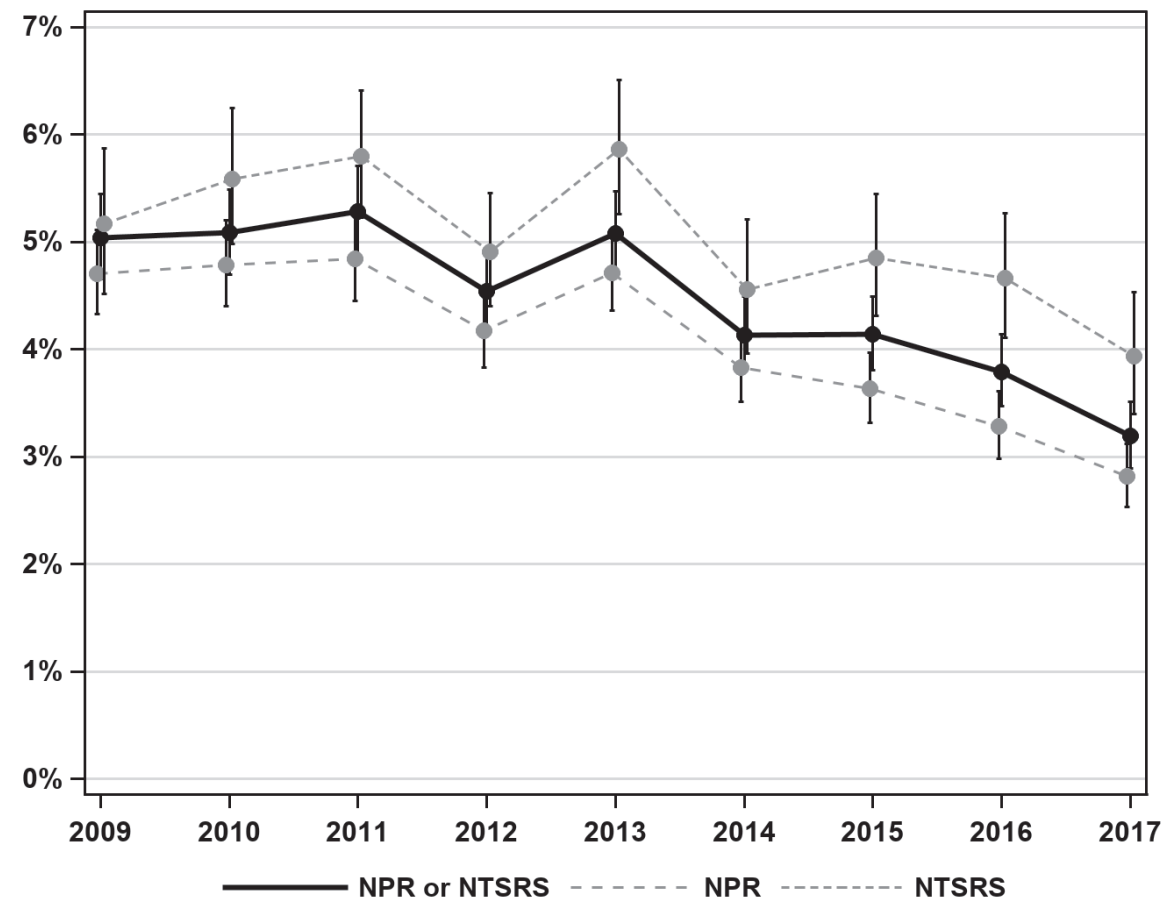


Figure 9

Admission rates for haemorrhage in the merged cohort quantified by surgical method 2009-2017

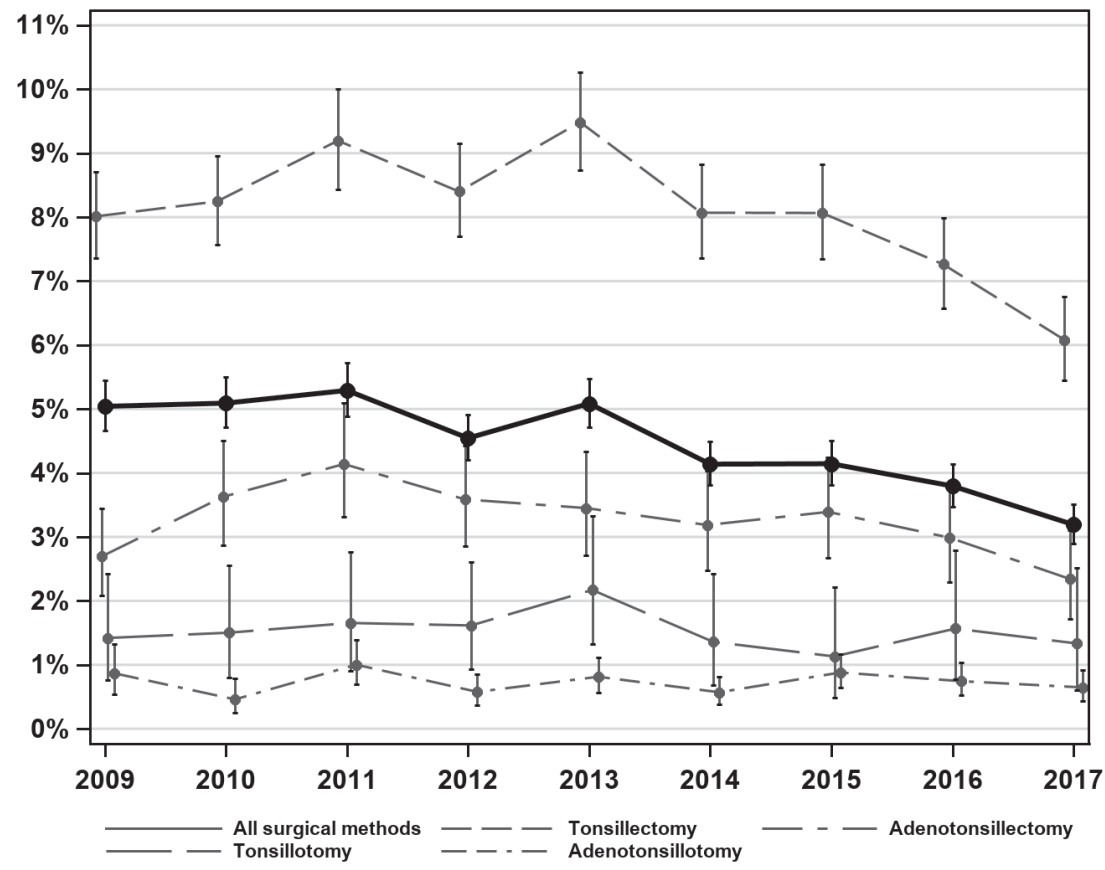

In the subgroup analyses, a significantly higher mean admission rate for haemorrhage $(8.0 \%)$ was found for tonsillectomy compared to all other surgical methods, with an RR of $5.17(4.83 ; 5.52), \mathrm{p}<0.0001$.

In the drop-out analysis (comparing NTSRS data to NPR data) there was a significantly higher admission rate for haemorrhage in responders to the 30-day questionnaire in the NTSRS compared to the rate in the nonresponders $(4.3 \%(4.1 ; 4.5)$ vs $3.9 \%(3.7 ; 4.1 \%), p=0.0095)$. The response rate was marginally higher for patients with admissions for haemorrhage (56.3\%) compared to non-bleeders $(54.0 \%), \mathrm{p}=0.0095$.

The linear regression model performed to determine the degree of linear correlation between the mean yearly admission rates for haemorrhage in the NPR and NTSRS showed close correlations for all surgical methods combined and for tonsillectomy. Moderate correlation was found for adenotonsillectomy, while poor and no correlation were found for adenotonsillectomy and tonsillotomy, respectively. 
Figure 10 Linear correlation mode (all surgical methods combined) The equation for the line: $y=$ $1.007 x-0.013, R^{2}=0.848$, Root MSE $=0.0004, p=0.0004$. The grey shaded area represents the prediction interval for the model

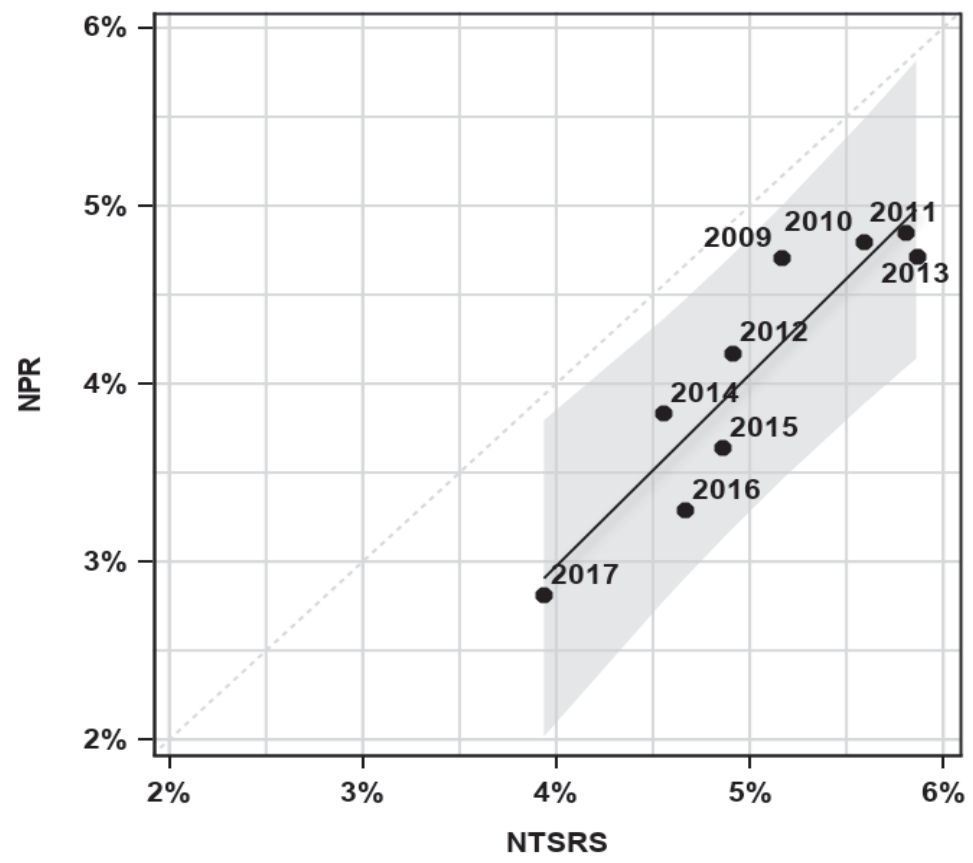

- Registered — Predicted

Percent and calculated agreement between the registers based on the matched cohort of surgeries, with information on haemorrhage events present in both registers, is presented in table 16. Strong agreement was found for the reporting of admission for haemorrhage between registers for all surgical methods. Significantly higher haemorrhage rates were reported in the NTSRS compared to the NPR $(\mathrm{p}<0.0023)$. The $2 \times 2$ contingency table for the agreement analysis of all surgical methods combined shows that more admissions were identified only in the NTSRS compared to only in the NPR, 424 vs 63 or $18 \%$ vs $2.7 \%$ of all admissions for bleeding in this matched cohort. 
Table 16

Comparing data on haemorrhage events in the NPR and the NTSRS

\begin{tabular}{c|c|cc|c}
\hline Surgical method & $\begin{array}{c}\text { matched cohort } \\
\text { (number of } \\
\text { surgeries in both } \\
\text { registers with data } \\
\text { on haemorrhage) }\end{array}$ & $\begin{array}{c}\text { agreement } \\
(\%)\end{array}$ & $\begin{array}{c}\text { Cohen 's Kappa } \\
\text { Coefficient } \\
(95 \% \text { Cl interval) }\end{array}$ & $\begin{array}{c}\text { haemorrhage } \\
\text { rate } \\
\text { NPR vs NTSRS } \\
\text { (p-value) }\end{array}$ \\
\hline $\begin{array}{c}\text { all surgical } \\
\text { methods }\end{array}$ & $\mathrm{n}=44554$ & $98.9 \%$ & $0.88(0.87 ; 0.89)$ & $\begin{array}{c}4.3 \% \text { vs } 5.1 \% \\
\mathrm{p}<0.0001\end{array}$ \\
tonsillectomy & $\mathrm{n}=18808$ & $98.4 \%$ & $0.90(0.89 ; 0.91)$ & $\begin{array}{c}8.1 \% \text { vs } 9.4 \% \\
\mathrm{p}<0.0001 \\
3.8 \% \text { vs } 4.6 \% \\
\mathrm{p}<0.0001\end{array}$ \\
adenotonsillectomy & $\mathrm{n}=6621$ & $98.7 \%$ & $0.83(0.80 ; 0.87)$ & $\begin{array}{c}1.3 \% \text { vs } 1.7 \% \\
\mathrm{p}=0.0023\end{array}$ \\
tonsillotomy & $\mathrm{n}=3019$ & $99.6 \%$ & $0.85(0.77 ; 0.93)$ & $0.6 \%$ vs $0.9 \%$ \\
$\mathrm{p}<0.0001$
\end{tabular}

\begin{tabular}{|c|c|c|c|c|}
\hline & & \multicolumn{2}{|c|}{ NTSRS } & \multirow[b]{2}{*}{ Total } \\
\hline & & $\begin{array}{l}\text { No admission } \\
\text { for haemorrhage }\end{array}$ & $\begin{array}{c}\text { Admission } \\
\text { for haemorrhage }\end{array}$ & \\
\hline \multirow{2}{*}{ NPR } & $\begin{array}{l}\text { No admission } \\
\text { for haemorrhage }\end{array}$ & $42219(94.76 \%)$ & $424(0.95 \%)$ & $42643(95.71 \%)$ \\
\hline & $\begin{array}{l}\text { Admission } \\
\text { for haemorrhage }\end{array}$ & $63(0.14 \%)$ & $1848(4.15 \%)$ & 1911 (4.29\%) \\
\hline & Total & $42282(94.90 \%)$ & $2272(5.10 \%)$ & $44554(100 \%)$ \\
\hline
\end{tabular}




\section{Discussion}

Burton et al. concluded, in the latest updated Cochrane review (2014) with the title "Tonsillectomy or adenotonsillectomy versus non-surgical treatment for chronic/recurrent acute tonsillitis", that there is evidence for a modest effect of (adeno)tonsillectomy, defined as a reduction in the number of episodes and days with sore throat, in children in the first year after surgery. ${ }^{37}$ The effect in adults is uncertain since insufficient information is available. Burton, as well as Paradise et al. (the authors behind the famous Paradise criteria), argue that the potential benefit of surgery must be weighed carefully against the risk of complications. ${ }^{37} 3956$ This reflection captures the essence of this thesis, which is to shed light on the effectiveness of tonsillectomy for throat infections and the current status of the most significant complication of tonsil surgery, postoperative haemorrhage.

\subsection{Is tonsillectomy an effective treatment for recurrent/chronic throat infections?}

Intuitively, the most relevant way to determine the benefit of a surgical procedure is to evaluate to what degree the procedure leads to resolution of the symptoms it was intended to treat. In recurrent throat infections, this implies reducing either the number or the severity of throat infections. This effect can be studied by asking the patients or caregivers or, as in paper I, objectively by comparing medical care visits for throat infections before and after intervention. The first approach will most likely tend to overestimate the prevalence of infections, while the latter will underestimate the prevalence, since not all patients seek medical attention for every throat infection. ${ }^{116} 117$

The main findings in paper I were that tonsillectomy in both children and adults reduced the number of medical care visits for tonsillitis and pharyngitis, with a difference in the change in mean yearly rate between the intervention and control group of -0.283 in children and -0.111 in 
adults. Patients who underwent surgery had fewer visits after surgery compared to before, and fewer visits compared to non-surgically treated patients. The effect of tonsillectomy in reducing medical care visits was small with greatest reductions observed within the first year after surgery. Overall a greater effect was observed in children compared to adults and in patients with a higher number of medical care visits before surgery.

In children, the articles by Paradise et al. and Van Staaij et al. are often referred to when discussing the effect of tonsillectomy for throat infections. ${ }^{39} 5657$ Paradise et al. found in their early study $(1984)^{39}$ that severely affected children, i.e those fulfilling the Paradise criteria, experienced clinically relevant effects of the procedure, measured by a reduction in the overall number of throat infections as well as the number of moderate to severe episodes. In the randomized arm of the study, a yearly mean number of throat infections of 1.54 was observed in the surgical group ((adeno)tonsillectomy) vs 2.65 in the control group during the three years of follow-up. The corresponding numbers for moderate or severe episodes were 0.17 vs 0.88 . Interestingly, in the conclusion the authors emphasized that the study contributed evidence for an effect of surgery in severely affected children but also for non-surgical management since few infections were generally also observed in the follow-up of non-surgically treated children. In their later study $(2002)^{56}$, Paradise et al. found a similar reduction in the number of episodes with throat infections in moderately affected children, with a mean yearly number of infections of 1.58 after tonsillectomy vs. 1.66 in the adenotonsillectomy group vs 2.63 in the control group during the three years of follow up. The corresponding numbers for moderate to severe episodes were 0.11 vs 0.09 vs 0.30 , hence, substantial lower for the control group compared to the severely affected children in their earlier study. Based on these results, the authors concluded that the degree of benefit with tonsillectomy do not justify the risks in moderately affected children. Worth a comment is also that the criteria used for inclusion in the later Paradise study was still more stringent than the recommendations in general use at the time in the US. ${ }^{56}$

Van Staaij et al. published a study on the effect of adenotonsillectomy in children with mild symptoms of throat infections (a median of 3 infections the year before surgery) in the BMJ 2004. ${ }^{57}$ This study showed a mean yearly number of throat infections (up to 24 months follow up) in the adenotonsillectomy group of 0.56 vs 0.77 in the watchful waiting group, with a mean difference of $-0.21(-0.36$ to -0.06$)$. The effect of 
surgery in reducing episodes of throat infections was greater in children with 3-6 infections within the qualifying year (mean difference of -0.49) compared to the effect in children with 0-2 infections (mean difference of -0.03). The authors concluded that adenotonsillectomy has no major clinical benefit over watchful waiting in children with mild symptoms of throat infections.

The children in paper I were mainly moderately or less affected by throat infections and therefore most comparable to the population in the Van Staaij study. The category C $(7+$ infections $)$ children can be compared to the population in the later Paradise study, but not all of the Category $\mathrm{C}$ patients would have fulfilled the inclusion criteria in this study. In summary, the results in paper I support the findings and conclusions in the presented studies; surgery has a small but not clinically relevant effect in children not severely affected. The more pronounced effect of surgery in patients with $7+$ medical care visits before intervention suggests that there might be a cut off where the statistically observed effect reaches clinical relevancy, as suggested by the Paradise criteria. However, no definition of what constitutes a clinically relevant effect has been established, and with only $15.1 \%$ of the children and $4.0 \%$ of the adults in paper I having had $\geq 7$ medical care visits before intervention, the number of included patients in this subcategory was too small to draw firm conclusion of the effect size in severely affected patients.

Only two randomized controlled trials in adults, by Alho et al. and Koskenkorva et al. were found eligible for inclusion in the Cochrane review by Burton et al. ${ }^{37}$ Alho et al. reported less frequent episodes of tonsillitis and pharyngitis after tonsillectomy in adults with $>3$ episodes of pharyngitis within the last 6 months (mean 3.3 episodes) or $>4$ infections within the last year (mean 4.8), whereof all episodes needed to be severe enough for the patient to seek medical attention, and at least one episode had to be a confirmed group A streptococcal infection. At 90 days, a $30 \%$ reduction in the number of episodes with pharyngitis requiring medical consultation was observed in the surgical group. In patients with recurrent streptococcal pharyngitis a mean of 0.1 medical consultations for pharyngitis were seen in the tonsillectomy group (follow-up 170 days) compared to 0.9 in the control group (follow-up 164 days).

Koskenkorva et al. reported a reduction in the mean number of medical visits for pharyngitis after tonsillectomy (mean of 0.1 visits 
$\pm \mathrm{SD} 0.5$ ) compared to watchful waiting (mean of 1.0 visits \pm SD1.4), with a mean follow-up of 6.2 months for the tonsillectomy group and 5.7 months for the watchful waiting group. The patients in this study needed to have at least 3 episodes of pharyngitis that affected daily activities and were severe enough to seek medical attention, within the last 12 months.

Comparing the results for adults in paper I with the presented studies is difficult because of the short follow-up in these studies. In paper I, tonsillectomy showed a benefit in reducing medical care visits for adults with $\geq 4$ medical care visits (in 2 years) but only for the first year of follow-up. The effect was overall less pronounced for adults compared to children, but for adults with 7+ visits (category C) similar to the effect observed in children. In current clinical practice, the Paradise criteria formulated based on studies in children are extrapolated to adults. Evaluation of the correctness of this practice has not been possible due to lack of evidence in adults; however, from paper I, there seems to be a similar relationship between the number of preoperative visits and the effect of tonsillectomy in adults as that seen in children.

The surgical group in paper I had remarkably few medical care visits before surgical intervention: $53.8 \%$ of the children and $70.1 \%$ of adults had less than four medical care visits during the preoperative 2 years, with a mean of 3.85 visits in children and 2.89 in adults. When the national guidelines in Sweden state that more than three or four infections in a I2-24 months period are necessary to qualify for surgery, this observation suggests unsatisfactory adherence to the guidelines. To put this in a global perspective, the Swedish guidelines require fewer infections compared to the Paradise criteria used in most countries with published national guidelines, which, in comparison, would require io infections in a 2-year period before surgery. The lack of a relevant number of infections could explain the small effect of tonsillectomy found in paper I and raises concerns about the relevance of the current clinical practice of tonsillectomy in Sweden. 


\subsection{What is the risk of bleeding after tonsil surgery?}

According to paper II, the readmission rate for haemorrhage in Sweden increased from $\mathrm{I} .12 \%$ in 1987 to $4.80 \%$ in 2013 , with a mean readmission rate of $2.61 \%$. From 2009 to 2017 , the mean admission rate for haemorrhage based on merged data from the NPR and the NTSRS was $4.5 \%$ (IV), and a significant decrease was observed, from 5.0\% in 2009 to $3.2 \%$ in 2017 . Looking at NPR data alone (IV), a reduction from a peak of $4.9 \%$ in 201 I to a low of $2.8 \%$ in 2017 was observed.

Figure II Secondary haemorrhage rates in Sweden

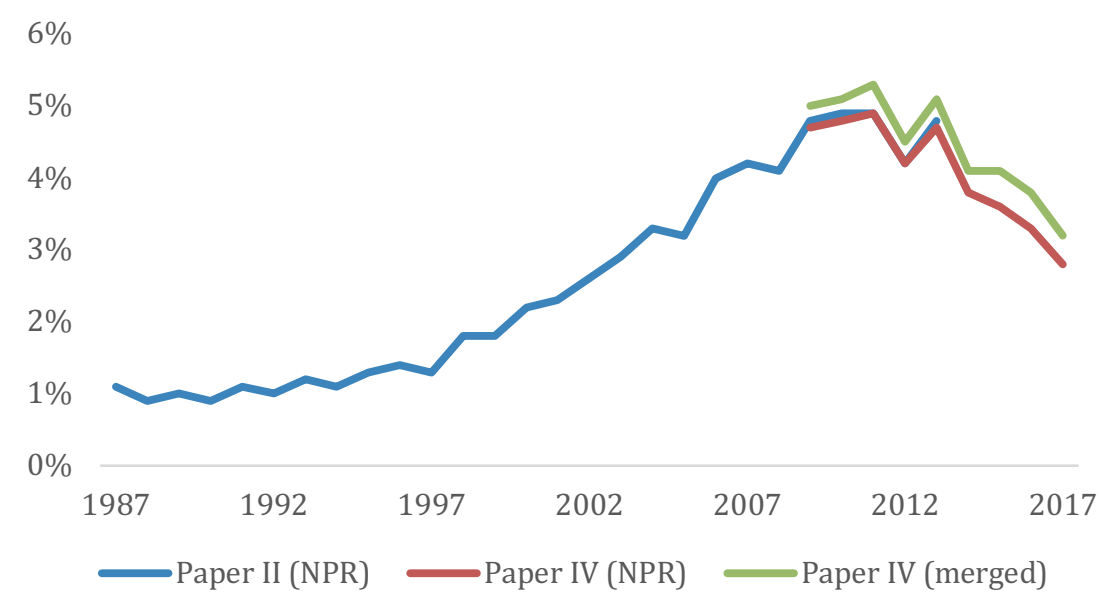

Data from paper II and IV are based on admissions or readmissions for haemorrhage defined in most studies as secondary haemorrhage. The rate of primary haemorrhage after tonsil surgery in Sweden from 1998-2007 was $1.3 \%$ (54 000 surgeries), with a significant decrease from $2.0 \%$ in 1997 to $0.96 \%$ in $2008 .{ }^{99}$ Other studies have reported rates of primary haemorrhage between $0.14 \%$ and $1.5 \%{ }^{118}$ The reason for the observed decrease in primary haemorrhage rates could not be determined in the Swedish study, but increase in the use of electrosurgery, changes in anaesthesiology methods and choice of postoperative analgesic drugs were suggested as possible contributing factors. ${ }^{99}$ Adding a primary haemorrhage rate to the secondary haemorrhage rates found in papers II 
and IV would give a complete haemorrhage rate after tonsil surgery of $3.91 \%(+1.3 \%)$ 1987-2013 and 5.5\% (+1.0\%) 2009-2017.

The numbers presented above from papers II and IV are not directly comparable. The data from paper IV are based on merged data from the two registers, NPR and NTSRS, while the data from paper II are based on the NPR alone. The linear regression analysis in Paper II showed that NTSRS-based secondary haemorrhage rates are approximately $1 \%$ higher than NPR rates. There are several possible explanations for this. In the NPR, only true readmissions for haemorrhage occurring after discharge were collected. This variable is somewhat different from the NTSRS variable, which is admission to hospital without a specified time frame. The NTSRS variable may thus also include primary bleedings, unplanned admissions after scheduled day surgery being an example. Another explanation for the discrepancy in reported rates could be participation bias, the dropout analysis in paper IV showed that responders to the 30day questionnaire on admission for haemorrhage had higher rates of secondary haemorrhage compared to non-responders, $4.1 \%$ vs $3.9 \%$, and patients with bleeding were somewhat more likely to answer the 30 -day questionnaire than non-bleeders $(56.3 \%$ vs $54.0 \%)$. A third possibility, illustrated by the higher number of admission events for haemorrhage identified only in the NTSRS in the agreement analysis (IV), is that NTSRS is a more sensitive source for identifying haemorrhage events than NPR. Finding the true explanation for the differences in secondary haemorrhage rates reported by the registers demands a proper validation of both registers.

The rate of secondary haemorrhage seems to have increased in Sweden until 2011 and thereafter decreased (figure 9). Neither paper II or paper IV was designed to provide an answer to why these changes have occured, and careful interpretation of causal relationships is important in retrospective studies.

Possible reasons for the increase in readmission rates from 1987 to 2011 discussed in paper II could be many. The introduction of diathermy and other warm techniques for haemostasis and dissection in the late $20^{\text {th }}$ century is one possible explanation. In 2012, bipolar diathermy was used alone or in combination with other techniques for haemostasis in 55.9\% of all tonsil surgeries in Sweden. ${ }^{109}$ In the time-period 2009-2013, only $7.4 \%$ of tonsil surgeries in Sweden were performed with cold dissection 
and cold haemostasis. ${ }^{48}$ Several studies have shown that warm technique is a risk factor for secondary haemorrhage. ${ }^{4849} 78858895$

Increased awareness of the risks associated with haemorrhage from the throat could explain a higher readmission rate for haemorrhage. Several studies published around the turn of the century suggested that minor haemorrhage events can precede more serious bleedings and that bleeding can be life threatening. ${ }^{194119}$ One of the fatal bleeding events identified in paper III occurred after a prior minor haemorrhage. In Sweden today, readmission is the standard of care for most cases of postoperative haemorrhage after tonsil surgery regardless of the severity of the haemorrhage. No publications have described how bleedings were handled in 1987, but it is possible that a lower proportion of patients with haemorrhage were readmitted.

The distribution of the postoperative day for which readmission for haemorrhage occurred was similar when comparing 1987 to 2013

(figure 6) suggesting that the pathophysiology behind the bleedings has not changed, despite increasing use of warm techniques.

Surprisingly, the decrease in length of stay (LOS) for inpatient surgery at the index operation, from a mean of 4 days in 1987 to 2 days in 2013, leaving the patients with more time available to experience secondary haemorrhage due to earlier discharge, did not seem to have had major impact on the observed increase in secondary haemorrhage rate (Adjusted OR 0.96) (II).

A decline in surgical skills and experience related to the reorganization of ENT-care in Sweden, with fewer tonsillectomies available to each surgeon due to an increasing share being performed in high volume outpatient centres, could have influenced both the training of new specialists and the preservation of skills in existing specialists. Conflicting evidence exists for the relationship between surgical experience and the risk of haemorrhage after tonsil surgery. ${ }^{83} 8588$

Intuitively, the main reason for the observed decrease in unadjusted rates of secondary haemorrhage from 2009 to 2017 is trend shifts for indications and surgical methods with increasing proportion of tonsil surgeries being performed as (adeno)tonsillotomies for upper airway obstructions in children, with significantly lower risk of PTH. ${ }^{45}$ This trend shift, however, was apparent before 2009 and should have influenced the rates in paper II as well. In addition, the risk of secondary haemorrhage decreased the most for tonsillectomies (figure 9). It is plausible that an increased awareness of the risks related to utilization of warm techniques for dissection and haemostasis, guided by large studies 
from the NTSRS, as well as yearly reports issued from the register, has influenced the haemorrhage rates $^{48109111}$ Quality improvement programmes initiated and supported by the steering committee for the NTSRS have shown that improving the haemorrhage rates at individual clinics is possible. ${ }^{110}$ The main intervention in these programs were recommendations for the use of cold techniques for dissection and haemostasis.

Reported haemorrhage rates after tonsil surgery vary from $0-29.1 \%$ in the literature. ${ }^{93}$ Sarny et al. reported a haemorrhage a rate of $15 \%$ after $\mathrm{TE} \pm \mathrm{AE}$ including primary haemorrhage, based on the Austrian multicentre audit initiated after 5 fatal events caused by bleeding in children below the age of 6 in 2006 and 2007. ${ }^{43}{ }^{83}$ Lowe et al. published considerably lower numbers from the prospective National Tonsil Audit in United Kingdom 2007, with an overall haemorrhage rate of $3.5 \%{ }^{88}$ From Germany, Windfuhr ${ }^{24}$ has reported a haemorrhage rate of $5.98 \%$ after $\mathrm{TE} \pm \mathrm{AE}$ in 2010 and 2013. Tomkinson et al. found a primary haemorrhage rate of $0.1 \%$ and a secondary haemorrhage rate of $1.8 \%$ after TE \pm AE based on data from the Surgical Instrument Surveillance Program (SISP) in Wales, 2003-2008. ${ }^{85}$ Blakely suggested, in a review published 2009, an expected mean bleeding rate of $4.5 \%+9.4 \%$ (2SD) after tonsillectomy as acceptable and that rates above this range justify monitoring. ${ }^{120}$ The Swedish rate of secondary haemorrhage after tonsillectomy of $8.0 \%$ (2009-2017) from paper IV are according to this recommendation within the expected range.

Paper II identified male gender, increasing age, infectious indication, tonsillectomy as the surgical method and outpatient care as risk factors for haemorrhage. Male gender and increasing age are known risk factors for postoperative haemorrhage after tonsillectomy. ${ }^{24} 2683859293$ Infectious indication, most often recurrent/chronic tonsillitis or peritonsillar abscess, have been found by others to be a risk factor for PTH, however Sarny et al. found no increased risk for recurrent tonsillitis, and lower risk for abscess tonsillectomy compared to all indications. ${ }^{22} 8384121122$ Most studies on risk factors report solely for tonsillectomies, and for that reason few studies have evaluated surgical method as a potential risk factor. However, most comparisons between tonsillectomies and tonsillotomies have showed significantly lower risk of PTH after tonsillotomy. ${ }^{14} 4145123$ 
Surprisingly, outpatient surgery was found to be a risk factor for secondary haemorrhage in the univariable, but not the multivariable model. Previous studies agree on the safety of outpatient tonsil surgery and generally no difference in PTH rates related to level of care have been found. ${ }^{124-126}$ The explanation for this finding in paper II was suggested related to a bias created when comparing a large group of inpatient surgeries performed early in the study period, when haemorrhage rates were low, with an outpatient group with higher number of surgeries performed late in the study period, when haemorrhage rates were higher.

Unfortunately, information on the surgical technique used is not available in the NPR, hence the risk of PTH related to surgical technique could not be determined. Most studies agree on a higher risk of secondary haemorrhage after tonsillectomy performed with warm techniques. ${ }^{48498385}$

\subsection{Is tonsillectomy for recurrent/chronic throat infections warranted?}

In all surgical decision-making, the anticipated benefit for the individual patient must be weighed carefully against the risk of complications or adverse effects. Providing evidence-based estimates of expected positive outcomes with regards to treating the pathology along with accurate rates of complications is vital for obtaining a truly informed consent, when surgery is indicated.

The effect of tonsillectomy is, as shown in paper I, modest with regard to reducing medical care visits in moderately or less affected children and adults. Children who underwent surgery had on average 0.283 fewer visits per year compared to patients who did not undergo surgery, while the difference in reduction was smaller in adults, -0.111 . The relative rate reduction the first year after surgery was $60 \%$ in children and $69 \%$ in adults with 7 or more infections before surgery, but the confidence intervals were large suggesting great insecurity in these estimates, and more importantly, and the main argument against surgery in these patients, is that the non-surgically treated patients had few medical care visits already within the first year of observation. The relative rate 
reductions were based on already low rates in patients not receiving surgery. These results have been confirmed by randomized controlled trials. ${ }^{39} 5657$ If, as suggested by Burton et al. in the Cochrane review 2014, the surgical events were counted in as one additional medical care visit in all surgically treated patients, the small observed effect of surgery would have been eliminated.

Patients are generally satisfied with the benefit of tonsillectomy, and there are several studies showing improvement in disease-specific and/or global quality of life. ${ }^{61}{ }^{63}$ However, no study will ever have the ability to confidently determine if the experienced effect is caused by the intervention, the benign nature of the disease or is a consequence of a regression to the mean. Again, a high degree of spontaneous resolution of symptoms in non-surgically treated patients favours against surgery.

Paper IV described an $8.0 \%$ mean admission rate for haemorrhage after tonsillectomy from 2009-2017 and adding primary haemorrhage would give a rate of approximately $9.0 \%$. Revisits or readmissions for fever/dehydration after tonsillectomy are not uncommon. ${ }^{66} 7386$ Rare serious adverse events may happen, including fatal events. In paper III both fatal events were due to bleeding, a finding in accordance with most previous reports, with mortality rates ranging from 1/ 1000 to less than 1/170 000. ${ }^{19} 7072119$ 127-131 Pain is inevitable after tonsillectomy, Paradise et al. reported a mean of 4.9 and 6.3 days with pain in children, Alho et al. 13 days in adults. ${ }^{3739565982}$ Burton et al. found a reduction of 4-5 days with sore throat after tonsillectomy children, counting in days of pain related to the surgical procedure. The corresponding number in adults were 10.6 days, but this estimate was not adjusted for the days of postoperative pain.

Surgery often requires days off work or school in the postoperative period, a recent Swedish study found an average of 6.2 days of work for caregivers after tonsillectomy in children with an average indirect cost of 1010 EUR. ${ }^{133}$ There are on the contrary evidence for overall fewer days of missed school or work in children after tonsillectomy, but only for the first year after surgery. ${ }^{134}$

In conclusion, if evidence-based medicine is the ideal, there seems to be an unattractive risk-benefit balance for tonsillectomy as treatment for recurrent throat infections in patients not fulfilling the Paradise criteria. This reflection will, however, not change the fact that some patients 
continue to have recurrent episodes of acute tonsillitis until their tonsils are removed. In the early Paradise study ${ }^{39}$ approximately $15 \%$ of the patients in the control group were withdrawn by their patients and received surgery each of the three follow up years. These patients had consistently higher number of throat infections compared to the remaining patients in the control group. The results in paper I cannot be generalized to severely affected patients (those fulfilling the Paradise criteria) since the disease burden with regard to the number of medical care visits was too low. Currently, we are not able to distinguish between the patients who will improve spontaneously from those who will continue to have infections. If the results in paper I is to be believed, a reasonable compromise would be to prolong the period of watchful waiting (for no longer than a year) for most patients not severely affected.

A few retrospective studies have shown comparable effects of tonsillotomy for treating recurrent tonsillitis. ${ }^{135-137}$ With the knowledge of the lower risk of bleeding and less postoperative pain with this procedure compared to tonsillectomy, the risk-benefit calculations would be quite different. However, further research is needed to determine the role of tonsillotomy in treating recurrent tonsillitis. 


\subsection{Limitations}

All studies in this thesis are retrospective cohort studies. Historically, the role of this study design is to monitor and investigate the clinical practice provided and generate hypotheses that later can be tested in randomized controlled trials. The study design does not offer any possibility to control possible confounding factors; hence, potential causal relationships must be carefully interpreted. Using medical care registers based on coding of medical conditions and procedures is also problematic. The quality of the output is no better than the quality of the input. Errors do occur in diagnostic practice, and variables able to be included in studies are limited to the variables available in the registers.

\section{Paper I}

There are four main concerns with the study design in paper I.

The intervention and control groups had few medical care visits during the follow-up period, and it is plausible that regression to the mean is part of the explanation for this. The effect of this bias is anticipated to be greatest for the patients with the highest number of preoperative medical care visits. However, intergroup differences should be unaffected by this phenomenon, and the long preoperative observation and long postoperative follow up should minimize this bias. Using the mean yearly visits rates of a three-year period of follow-up as a primary outcome variable was aimed at reducing the risk of regression to the mean. ${ }^{138}$

Due to the retrospective design and limited number of variables available in the VEGA register, it was not possible to evaluate the circumstances leading to the decision for surgery in the included patients; hence, selection bias may have occurred. It is possible that the surgical group comprised of more severely affected patients compared to the control group, hence their selection for surgery. The number of medical care visits is only one measure of disease burden; other studies have used days with sore throat, days with fever, days off school or work, or quality of life measures to complement the evaluation of morbidity and disease severity. These variables are unfortunately not available in the VEGA register. The aim of the matching procedure was to minimize selection bias.

The quality of coding in the primary care sector in Sweden is not known. Distinguishing between tonsillitis and pharyngitis can be difficult or 
impossible, as these diseases can co-exist. A national guideline to aid in diagnostic practice and treatment of throat infections in the primary care setting exists; however, this guideline treats tonsillitis and pharyngitis as one entity, pharyngotonsillitis. ${ }^{139}$ In paper I, the difficulties in diagnostic practice were clearly demonstrated by the observed coding of tonsillitis in surgical patients after removal of the tonsils. However, since both pharyngitis and tonsillitis codes were included in the qualifying codes for a relevant medical care visit, this bias was most likely of minor importance.

Great controversy exists to whether chronic tonsillitis constitutes a separate medical condition and if it does, there is no consensus regarding the biological background for recurrent vs chronic tonsillitis. The French guidelines for paediatric tonsillectomy define chronic tonsillitis as local and regional signs of inflammatory disease related to the tonsils with symptoms such as pharyngeal pain, halitosis, and cervical adenopathy. ${ }^{\mathrm{I}}{ }^{\mathrm{O}}$ Burton et al. suggest that chronic tonsillitis be defined as symptoms of tonsillitis present for more than 3 months. ${ }^{37}$ Windfuhr et al. stated in a clinical guideline for the management of tonsillitis and a systematic review of indications for tonsillectomy (20I6) that terms such as "sore throat", "chronic" and "recurrent acute tonsillitis" are poorly defined and used inconsequently in the literature, and that the term "chronic tonsillitis" should no longer be used. ${ }^{28}{ }^{36}$

The definition problems are exacerbated in paper I by the fact that chronic tonsillitis has a unique code in the ICDio coding system while recurrent tonsillitis does not, hence a differentiation between recurrent and chronic tonsillitis was not possible. Unfortunately, the new ICD-II coding system does not seem to make the distinction any clearer. ${ }^{\text {III }}$ If chronic tonsillitis is to be considered different from recurrent tonsillitis, the reduction in medical care visits may not be the best way to estimate the effect of tonsillectomy, and the results of paper I could underestimate the true effect of the procedure.

\section{Paper II}

All data in paper II were retrieved from the NPR. No published validation of outpatient procedures in the NPR exists. An external review and validation of inpatient data in the NPR was published in $201 \mathrm{I}$ by Ludvigsson et al., and in this article, the coverage of outpatient procedures based on data from $1997-2007$ was $80 \%$, with missing data 
primary from private caregivers. ${ }^{107}$ No description of how this proportion was estimated has been found in the original reference, which instead states that of the reported visits in outpatient care $80 \%$ have information on a primary diagnosis. ${ }^{\mathrm{I} 2}$ However, paper IV included matched data on the number of surgeries in the NPR and the NTSRS and found a coverage rate of the NPR compared to merged data of $94.6 \%$. This is the best estimate we have on the coverage of tonsil surgeries in the NPR, and it is probably close to the true number. The Swedish ENT community is small and transparent, and by the authors knowledge no large volume units offering tonsil surgery services fail to report to any register.

Papers II (and III and IV) are based on inpatient and outpatient data from the NPR defined by ICD codes. The validation of inpatient care reported by Ludvigsson et al. consisted of comparisons between ICD coding in the NPR and information available in the medical records of the patients. The study reported a positive predictive value (PPV) of diagnoses in the NPR of $85-95 \%$, but throat-infection related diagnoses or tonsil surgery were not among the evaluated diagnoses. Different possible errors of diagnostic practice were discussed in the article. Diagnostic error means the patient received an ICD code that did not cover the complaint, and translation error means that the code listed in the patient chart was not correctly transferred to the NPR. Coding errors comprise the use of the wrong ICD code for an otherwise correct diagnosis. All these different coding-related challenges influence the quality of the output from the NPR. In addition, the NPR is currently used to direct governmental reimbursement for care provided, and there is a financial incentive for the selection of diagnostic codes that offer the better reimbursement. The positive predictive values of the diagnoses of the patients included in paper II, III, IV are probably in the higher end of the estimate provided by Ludvigsson et al., since a readmission for haemorrhage required a previously registered surgical event.

Readmission for haemorrhage was defined as readmission within postop day I and 30 with an ICD-IO code suggesting bleeding from the head and neck. The codes defining bleeding were found by manually going through the list of all ICD codes, and were quality checked with their actual observed frequencies in our cohort. It is possible that important codes used for haemorrhage were left out, and also that haemorrhage events not related to the surgery was erroneous included as PTH. The list of qualifying codes used to define haemorrhage in paper II was somewhat 
more extensive than the list used in paper IV. The codes left out in paper IV were all S-codes, most often used to code injuries to the head/neck, and they occurred in very low frequencies, hence this discrepancy is unlikely to have influenced the results in any major way.

It is also possible that the admitting physician used the code for the indication for surgery when readmitting a patient for haemorrhage. In conclusion the NPR is not validated for tonsil surgery codes, and the codes defining haemorrhage in paper II (and IV) were also not validated.

A large decrease in the number of tonsil surgeries was observed between I996 and 2008. No obvious explanation for this was found, even after contact with the NBHW. It is possible that a weakness in reporting or a failure in data collection occurred, as a true decrease of this magnitude is considered less likely. The ICD-IO was implemented in 1997, replacing the ICD-9 coding system, and this could be a possible explanation for reporting problems. An error in reporting the number of surgeries, if such an error exists, could have a noticeable impact on the estimated haemorrhage rates, calculated directly as the number of readmissions for haemorrhage divided by the number of tonsil surgeries.

All studies of haemorrhage complications after surgery should include both a description of frequency and severity. One of the main reasons for the great variation seen in reported haemorrhage rates after tonsil surgery is probably differences in definitions of haemorrhage. ${ }^{93}$ Unfortunately the NPR does not contain information on the severity of haemorrhage beyond information on reoperation. The value of information on severity of PTH was impressively demonstrated by Sarny et al., which used this information to issue a recommendation for readmission to hospital for all patients experiencing a minor postoperative haemorrhage for I night, as $4 \mathrm{I} \%$ of patients with a minor bleeding episode experienced a second severe bleeding episode the following day. ${ }^{83}$

Many analyses were performed in paper II, and one could argue that using $99 \%$ CI intervals when analysing the data would have been more appropriate according to the principles of Bonferroni. Looking at the data from the paper, however, this would have had no impact on the results, given that most tests were highly significant. 


\section{Paper III}

Studying exceedingly rare events is difficult and not practically possible with RCTs. The study design in paper III was very simple and did not involve any advanced statistical tests. The problem, however, is the inherent instability of the mortality rate estimate. Missing one single fatal event would drastically change the mortality rate, and for this reason even with over 82000 observations, the confidence interval was very wide. Again, an advantage of being a small country with a small transparent ENT community is that, when fatal events occur, they tend to draw attention and rarely go by unnoticed.

\section{Paper IV}

Paper IV has several limitations. Data in the NTSRS rely on questionnaires filled out by surgeons and patients. The questionnaires have not been formally validated, and therefore, the quality of data in the NTSRS is not known. The response-rate from 2009-20I7 was 54.I\%, which is acceptable from an international perspective but far from complete. The NTSRS had a mean coverage of $75.2 \%$ of tonsil surgeries compared to the merged cohort. This means that data on admission for haemorrhage was only available for $40.8 \%$ of the surgical population defined by the merged cohort. Comparing responders and non-responders to the NPR revealed a significantly higher haemorrhage rate in responders compared to non-responders and patients with haemorrhage were more likely to respond to the 30-day questionnaire. This introduces a risk of attrition bias or participation bias.

Paper IV compared true readmissions for haemorrhage in the NPR with admissions (without a specified timeframe) for haemorrhage in the NTSRS. These variables may not be directly comparable. The importance of this limitation is handled in the discussion.

In addition, the limitations related to the quality of coding and the definition of postoperative haemorrhage in the NPR, as described in the paper II limitations, also apply to paper IV. 


\section{Conclusions}

Tonsillectomy is not clinically effective in reducing medical care visits for tonsillitis or pharyngitis in moderately or less affected children and adults. Statistically, there was a small reduction in mean yearly number of medical care visits after surgery compared to the reduction observed in non-surgically treated patients. The effect of surgery was more pronounced for children, for patients with a higher number of medical care visits before surgery and for the first follow-up year. Most patients had few medical care visits in the follow-up period regardless of surgical intervention.

The readmission rate for haemorrhage from $1987-2013$ was $2.61 \%$ while the reoperation rate for haemorrhage was $0.84 \%$. The rate increased from I.I $2 \%$ in 1987 to $4.80 \%$ in 2013 . The increase in readmission rate was most pronounced for adults who underwent tonsillectomy for infectious disease. Independent risk factors for haemorrhage were male gender, increasing age, infectious indication and tonsillectomy as surgical method.

The mortality rate after benign tonsil surgery in Sweden was I/4I 263 surgeries.

High inter-rater reliability for reporting of haemorrhage events between the NPR and the NTSRS was found for all surgical methods. Merging of data increased the number of surgeries and haemorrhage events available for calculating the admission rate for haemorrhage in Sweden (secondary haemorrhage rate).

In summary, the effect of tonsillectomy for recurrent/chronic throat infections, if measured by a reduction in medical care visits, does not seem to justify the risks associated with the procedure in patients moderately or less affected. 


\section{Future Perspectives}

Ideally, a new RCT to evaluate the benefit and complication rates for tonsillectomy performed for recurrent and chronic tonsillitis, differentiated, is needed, at least in adults. A randomized controlled trial of the clinical and cost effectiveness of tonsillectomy in adults is ongoing in the UK (The NATTINA study, www.nattina.com). ${ }^{I 43}$ The study closed for inclusion in April 20I8, with 453 participants from 22 sites in the UK, and results are expected to be published 2020. The study included patients $\geq$ I6 years of age with recurrent tonsillitis fulfilling the Scottish SIGN guidelines for the number of preoperative infections, which are identical to the Paradise criteria. ${ }^{144}$ The primary outcome measure will be the number of sore throat days over a period of 24 months after surgery. The secondary outcome measures will be frequency, severity, health and economic impact of any sore throat episodes experienced, QOL measurements, the number of adverse events, and qualitative feedback from patients and clinicians.

Each of the ambitious Paradise studies took over Io years to complete, and it is unlikely that a new RCT evaluating tonsillectomy for recurrent tonsillitis in children would be undertaken within the near future. A large number of patients would need to be screened and included to enable the necessary subgroup analyses, and a high level of crossover would be expected, at least in severely affected children. The NATTINA study offered patients deferred surgery to avoid cross over, but this may be harder to achieve in children. However, an RCT comparing tonsillectomy to tonsillotomy in children as treatment for recurrent throat infections is not unlikely to see the light of day within a foreseeable future.

Based on this thesis there is a need to revise the Swedish recommendations for performing tonsillectomy for recurrent tonsillitis. The required number of qualifying infections should probably be raised to the level of the Paradise criteria, since this is the only cut off with evidence of a clinically relevant effect. Based on paper I, up to a year of watchful waiting should be used for patients not fulfilling the criteria on initial evaluation. In addition, the criteria should be formulated more precisely with regard to the qualifying period for infections, and a clear 
differentiation between chronic and recurrent tonsillitis is desirable. There are no relevant studies published on the effect of tonsillectomy on chronic tonsillitis, so no recommendations for this entity can be made.

A standardized reporting system for postoperative haemorrhage after tonsillectomy, preferable including timing, location and severity of the bleeding would enable easier comparisons between reported rates and can be useful in designing guidelines or algorithms for the treatment of these patients..$^{83} \mathrm{I} 45$

The secondary haemorrhage rates in Sweden are decreasing according to paper IV. This is probably due to an increased focus on this complication and more careful use of warm techniques for dissection and haemostasis. This knowledge would not have been available without the NTSRS. An increase in both coverage and completeness and response rate to the 30day questionnaire would lead to even better data output from the register. Most importantly, however, validation of the NTSRS is planned and expected to be initiated 2020 . 


\section{Acknowledgements}

Without the people on this list the doctoral thesis would not exists. I would like to express my sincere gratitude to all of you.

To Joacim Stalfors, my main supervisor, thank you for all the constructive talks, the endless hours you put in trying to turn my writing into understandable text, for your encouragement in times when motivation was running low, and for your endless optimism. This thesis exists only because of you.

To Ola Sunnergren, my assistant supervisor, thank you for the all the critical reviews and comments, and for your good sense of humour.

Thank you to all my co-authors and the steering committee of the National Tonsil Surgery Register in Sweden, for constructive advice and for sharing your knowledge; Joacim Stalfors, Ola Sunnergren, Claes Hemlin, Elisabeth Ericsson, Elisabeth Hultcrantz, Anne-Charlotte Hessen Söderman, Pia Froissart Nerfeldt, Erik Odhagen and Fredrik Alm.

To Bengt Bengtsson, my favourite statistician in the whole world, thank you for comprehensive statistical assistance with all the papers, for redoing all the work when I suddenly changed my mind, and for your meticulous focus on details. Working with big data is challenging but you made it seem simple.

To Nils-Gunnar Pehrsson for help with statistical reviews and valuable input.

To statisticians Henrik Passmark and Fredik Hasselström at the National Board of Health and Welfare (Socialsstyrelsen) for help with data retrieval. 
To former and current head of the Department of Otorhinolaryngology, Sahlgrenska, Radi Jönsson and Erik Renvall, for encouraging and allowing us clinicians to invest time in research.

To head of the ENT department at Sahlgrenska Academy, Johan Hellgren, for creating a healthy research environment at the Department of Otorhinolaryngology at Sahlgrenska, and for helping out with administrative issues.

To Henrik Bergquist and Kaarina Sundelin for taking a chance on hiring me as a fresh registrar at the ENT department at Sahlgrenska.

To Hasse Ejnell, Luaay Aziz, Ali Adnan and all my other colleagues at Sahlgrenska for making my residency educational and fun. I learned from the best.

To my parents (Bjørg Østvoll og Svein Østvoll) for being the perfect parents any child could wish for, and for being supportive and believing in me always.

To my wife Yanti and my daughter Kiera for being patient for all the time invested in this project. 


\section{References}

I McNeill RA. A History of Tonsillectomy: Two Millenia of Trauma, Haemorrhage and Controversy. Ulster Med J I960;29:59-63.

2 Hultcrantz E, Ericsson E. Factors influencing the indication for tonsillectomy: a historical overview and current concepts. ORL $J$ Otorhinolaryngol Relat Spec. 2013;75:I84-9I.

3 Koempel JA. On the origin of tonsillectomy and the dissection method. Laryngoscope. 2002;II2:I583-86.

4 Karatzanis A, Trompoukis C, Vlastos I, Velegrakis G. On the history of modern tonsillectomy: the contribution of Nikolaos Taptas. Eur Arch Otorhinolaryngol. 20II;268:1687-89.

5 Rosenfeld RM, Green RP. Tonsillectomy and adenoidectomy: changing trends. Ann Otol Rhinol Laryngol. 1990;99:I87-9I.

6 Koempel JA, Solares CA, Koltai PJ. The evolution of tonsil surgery and rethinking the surgical approach to obstructive sleep-disordered breathing in children. J Laryngol Otol. 2006; I20:993-I000.

7 Parker NP, Walner DL. Trends in the indications for pediatric tonsillectomy or adenotonsillectomy. Int J Pediatr Otorhinolaryngol. 20II;75:282-85.

8 Carroll T, Ladner K, Meyers AD. Alternative surgical dissection techniques. Otolaryngol clin North Am. 2005;38:397-4II.

9 Weimert TA, Babyak JW, Richter HJ. Electrodissection tonsillectomy. Arch Otolaryngol Head Neck Surg. I990;II6:I86-88.

IO Blomgren K, Qvarnberg YH, Valtonen HJ. A prospective study on pros and cons of electrodissection tonsillectomy. Laryngoscope. 200I;III:47882 .

II Silveira H, Soares JS, Lima HA. Tonsillectomy: cold dissection versus bipolar electrodissection. Int J Pediatr Otorhinolaryngol. 2003;67:345-5I.

I2 Schloss MD, Tan AK, Schloss B, Tewfik TL. Outpatient tonsillectomy and adenoidectomy: complications and recommendations. Int J Pediatr Otorhinolaryngol. I994;30:II5-22.

I3 Boss EF, Marsteller JA, Simon AE. Outpatient tonsillectomy in children: demographic and geographic variation in the United States, 2006. $J$ Pediatr. 20I2;I60:8I4-I9.

I4 Windfuhr JP, Werner JA. Tonsillotomy: it's time to clarify the facts. Eur Arch Otorhinolaryngol. 2013;270:2985-96.

I5 Bajaj Y, Hore I. Diseases of tonsils, tonsillectomy and tonsillotomy. In: Watkinson JC, Clarke RW. Scott-Brown`s Otorhinolaryngology Head \& Neck Surgery, eight edition, volume 2. Boca Raton, FL. CRC press Taylor \& Francis Group; 20I9. p. 435-36. 
Eibling D. The Oral Cavity, Pharynx, Esophagus. In Lee KJ. Essential Otolaryngology Head\&Neck Surgery. Tenth Edition. The McGraw-Hill Companies; 2008. p. 509-IO.

I7 Van Abel KM, Moore EJ. Transoral Approaches to Malignant Neoplasms of the Oropharynx. In: Flint PW, Haughley BH, Lund V, et al. Cummings Otolaryngology Head and Neck Surgery Sixth Edition. Volume 2.

Philadelphia. Elsevier Saunders; 20I5. p. I455-57.

I8 Deutsch MD, Kriss VM, Willging JP. Distance between the tonsillar fossa and internal carotid artery in children. Arch Otolaryngol Head Neck Surg. I995;I2I:I4IO-I2.

I9 Windfuhr JP, Schloendorff G, Baburi D, Kremer B. Lethal outcome of post-tonsillectomy hemorrhage. Eur Arch Otorhinolaryngol. 2008;265:1527-34.

20 Stachler RJ, Shibuya TY, Golub JS, Pasha R. General Otolaryngology. In: Pasha R. Otolaryngology Head and Neck Surgery Clinical reference guide. Third edition. San Diego. Plural Publishing; 20II. p. 206-07.

2I Windfuhr JP, Sesterhenn AM, Schloendorff G, Kremer B. Posttonsillectomy pseudoaneurysm: an underestimated entity? J Laryngol Otol. 20I0;124:59-66.

22 Schrock A, Send T, Heukamp L, Gerstner AO, Bootz F, Jakob M. The role of histology and other risk factors for post-tonsillectomy haemorrhage. Eur Arch Otorhinolaryngol. 2009;266:1983-87.

23 Van Den Akker EH, Hoes AW, Burton MJ, Schilder AG. Large international differences in (adeno)tonsillectomy rates. Clin Otolaryngol Allied Sci. 2004;29:I6I-64.

24 Windfuhr JP. Specified data for tonsil surgery in Germany. GMS Curr Top Otorhinolaryngol Head Neck Surg. 20I6; I5:Doco8.

25 Borgstrom A, Nerfeldt P, Friberg D, Sunnergren O, Stalfors J. Trends and changes in paediatric tonsil surgery in Sweden I987-2013: a populationbased cohort study. BMJ Open. 2017;7:eor3346.

26 Windfuhr JP, Chen YS. Do changing trends in tonsil surgery affect hemorrhage rates? A longitudinal study covering I,452,637 procedures. Eur Arch Otorhinolaryngol. 2019;276:2585-93.

27 Sakki A, Mäkinen LK, Roine RP, Nokso-Koivisto J. Changing trends in pediatric tonsil surgery. Int J Pediatr Otorhinolaryngol. 20I9;II8:84-89.

28 Windfuhr JP. Indications for tonsillectomy stratified by the level of evidence. GMS Curr Top in Otorhinolaryngol Head Neck Surg. 20I6;15:Doco9.

29 Lumeng JC, Chervin RD. Epidemiology of pediatric obstructive sleep apnea. Proc Am Thorac Soc. 2008;5:242-52.

30 Marcus CL, Brooks LJ, Draper KA, et al. Diagnosis and management of childhood obstructive sleep apnea syndrome. Pediatrics. 20I2;I30:e7I4-55

3I Bourke R, Anderson V, Yang JS, et al. Cognitive and academic functions are impaired in children with all severities of sleep-disordered breathing. Sleep Med. 20II;12:489-96. 
32 Kaditis AG, Alonso Alvarez ML, Boudewyns A, et al. Obstructive sleep disordered breathing in 2- to I8-year-old children: diagnosis and management. Eur Respir J. 2016;47:69-94.

33 Raghunathan VM, Whitesell PL, Lim SH. Sleep-disordered breathing in patients with sickle cell disease. Ann Hematol. 20I8;97:755-62.

34 Aurora RN, Casey KR, Kristo D, et al. Practice parameters for the surgical modifications of the upper airway for obstructive sleep apnea in adults. Sleep. 20I0;33:I408-I3.

35 Holmlund T, Franklin KA, Levring Jäghagen E, et al. Tonsillectomy in adults with obstructive sleep apnea. Laryngoscope. 20I6;126:2859-62.

36 Windfuhr JP, Toepfner N, Steffen G, Waldfahrer F, Berner R. Clinical practice guideline: tonsillitis I. Diagnostics and nonsurgical management. Eur Arch Otorhinolaryngol. 2016;273:973-87.

37 Burton MJ, Glasziou PP, Chong LY, Venekamp RP. Tonsillectomy or adenotonsillectomy versus non-surgical treatment for chronic/recurrent acute tonsillitis. Cochrane Database Syst Rev. 20I4:CDooI802.

38 Stuck BA, Gotte K, Windfuhr JP, Genzwurker H, Schroten H, Tenenbaum T. Tonsillectomy in children. Dtsch Arztebl Int. 2008;I05:852-60.

39 Paradise JL, Bluestone CD, Bachman RZet al. Efficacy of tonsillectomy for recurrent throat infection in severely affected children. Results of parallel randomized and nonrandomized clinical trials. New Engl J Med. I984;310:674-83.

40 The Swedish Association of Local Authorities and Regions. Report on National Medical Indications for Tonsil Surgery in Sweden. Stockholm; 2009. Available only in Swedish at www.tonsilloperation.se

4I Zhang LY, Zhong L, David M, Cervin A. Tonsillectomy or tonsillotomy? A systematic review for paediatric sleep-disordered breathing. Int $J$ Pediatr Otorhinolaryngol. 20I7;I03:4I-50.

42 Odhagen E, Sunnergren O, Hemlin C, Hessen Söderman AC, Ericsson E, Stalfors J. Risk of reoperation after tonsillotomy versus tonsillectomy: a population-based cohort study. Eur Arch Otorhinolaryngol. 20I6;273:3263-68.

43 Sarny S, Habermann W, Ossimitz G, Stammberger H. What lessons can be learned from the Austrian events? ORL J Otorhinolaryngol Relat Spec. 20I3;75:I75-8I.

44 Sunnergren O, Hemlin C, Ericsson E, et al. Radiofrequency tonsillotomy in Sweden 2009-2012. Eur Arch Otorhinolaryngol. 20I4;271:1823-27.

45 Odhagen E, Stalfors J, Sunnergren O. Morbidity after pediatric tonsillotomy versus tonsillectomy: A population-based cohort study. Laryngoscope. 20I8; doi:I0.I002/lary.27665. (E-pub ahead of print).

46 Blanchford H, Lowe D. Cold versus hot tonsillectomy: state of the art and recommendations. ORL J Otorhinolaryngol Relat Spec. 2013;75:136-4I.

47 Gysin C, Dulguerov P. Hemorrhage after tonsillectomy: does the surgical technique really matter? ORL J Otorhinolaryngol Relat Spec. 2013;75:I2332 . 
48 Söderman AC, Odhagen E, Ericsson E, et al. Post-tonsillectomy haemorrhage rates are related to technique for dissection and for haemostasis. An analysis of I5734 patients in the National Tonsil Surgery Register in Sweden. Clin Otolaryngol. 2015;40:248-54.

49 Lowe D, van der Meulen J, National Prospective Tonsillectomy Audit. Tonsillectomy technique as a risk factor for postoperative haemorrhage. Lancet. 2004;364:697-702. Erratum in Lancet. 2005 Sep 39;366(9488):808.

50 Hallenstål N, Sunnergren O, Ericsson E, et al. Tonsil surgery in Sweden 2013-20I5. Indications, surgical methods and patient-reported outcomes from the National Tonsil Surgery Register. Acta Otolaryngol. 20I7; I37:I096-IIO3.

5I Mangiardi J, Graw-Panzer KD, Weedon J, Regis T, Lee H, Goldstein NA. Polysomnography outcomes for partial intracapsular versus total tonsillectomy. Int J Pediatr Otorhinolaryngol. 20I0;74:I36I-66.

52 Friedman M, Wilson M, Lin HC, Chang HW. Updated systematic review of tonsillectomy and adenoidectomy for treatment of pediatric obstructive sleep apnea/hypopnea syndrome. Otolaryngol Head Neck Surg. 2009;I40:800-808.

53 Nakata S, Noda A, Yanagi E, Suzuki K, Yamamoto H, Nakashima T. Tonsil size and body mass index are important factors for efficacy of simple tonsillectomy in obstructive sleep apnoea syndrome. Clin Otolaryngol. 2006;3I:4I-45.

54 Baudouin R, Blumen M, Chaufton C, Chabolle F. Adult sleep apnea and tonsil hypertrophy: should pharyngoplasty be associated with tonsillectomy? Sleep Breath. 2019;23:917-23.

55 Mitchell RB, Archer SM, Ishman SL, et al. Clinical Practice Guideline: Tonsillectomy in Children (Update). Otolaryngol Head Neck Surg. 20I9; I60:SI-S42.

56 Paradise JL, Bluestone CD, Colborn DK, Bernard BS, Rockette HE, KursLasky M. Tonsillectomy and adenotonsillectomy for recurrent throat infection in moderately affected children. Pediatrics. 2002;IIO:7-I5.

57 van Staaij BK, van den Akker EH, Rovers MM, Hordijk GJ, Hoes AW, Schilder AG. Effectiveness of adenotonsillectomy in children with mild symptoms of throat infections or adenotonsillar hypertrophy: open, randomised controlled trial. BMJ. 2004;329:65I.

58 Lock C, Wilson J, Steen N, et al. North of England and Scotland Study of Tonsillectomy and Adeno-tonsillectomy in Children(NESSTAC): a pragmatic randomised controlled trial with a parallel non-randomised preference study. Health Technol Assess. 20I0; I4:I-I64, iii-iv.

59 Alho OP, Koivunen P, Penna T, Teppo H, Koskela M, Luotonen J. Tonsillectomy versus watchful waiting in recurrent streptococcal pharyngitis in adults: randomised controlled trial. BMJ. 2007;334:939.

60 Koskenkorva T, Koivunen P, Koskela M, Niemela O, Kristo A, Alho OP. Short-term outcomes of tonsillectomy in adult patients with recurrent pharyngitis: a randomized controlled trial. CMAJ. 20I3;I85:E33I-36. 
6I Stalfors J, Ericsson E, Hemlin C, et al. Tonsil surgery efficiently relieves symptoms: analysis of 54696 patients in the National Tonsil Surgery

Register in Sweden. Acta Otolaryngol. 20I2;I32:533-39.

62 Goldstein NA, Stewart MG, Witsell DL, et al. Quality of life after tonsillectomy in children with recurrent tonsillitis. Otolaryngol Head Neck Surg. 2008;I38:S9-Si6.

63 Witsell DL, Orvidas LJ, Stewart MG, et al. Quality of life after tonsillectomy in adults with recurrent or chronic tonsillitis. Otolaryngol Head Neck Surg. 2008;138:Si-S8.

64 Douglas CM, Lang K, Whitmer WM, Wilson JA, Mackenzie K. The effect of tonsillectomy on the morbidity from recurrent tonsillitis. Clin

Otolaryngol. 2017;42:1206-IO.

65 De Luca Canto G, Pacheco-Pereira C, Aydinoz S, et al.

Adenotonsillectomy Complications: A Meta-analysis. Pediatrics. 20I5;I36:702-I8.

66 Seshamani M, Vogtmann E, Gatwood J, Gibson TB, Scanlon D. Prevalence of complications from adult tonsillectomy and impact on health care expenditures. Otolaryngol Head Neck Surg. 20I4;I50:574-8I.

67 Heiser C, Landis BN, Giger R, et al. Taste disorders after tonsillectomy: a long-term follow-up. Laryngoscope. 20I2;I22:I265-66.

68 Onerci M, Ogretmenoglu O, Ozcan OE. Atlantoaxial subluxation after tonsillectomy and adenoidectomy. Otolaryngol Head Neck Surg. I997;II6:27I-73.

69 Garnett JD, Ramadan HH. Swallowing dysfunction after tonsillectomy. Otolaryngol Head Neck Surg. I996;II4:8I3-I7.

70 Goldman JL, Baugh RF, Davies L, et al. Mortality and major morbidity after tonsillectomy: etiologic factors and strategies for prevention. Laryngoscope. 20I3;I23:2544-53.

7I Lago DM, Koning JL, Naheedy J, Leuin S. Carotid artery pseudoaneurysm: A rare complication following tonsillectomy. Int $J$ Pediatr Otorhinolaryngol. 2015;79:2428-32.

72 Randall DA, Hoffer ME. Complications of tonsillectomy and adenoidectomy. Otolaryngol Head Neck Surg. I998;II8:6I-68.

73 Bhattacharyya N, Kepnes LJ. Revisits and postoperative hemorrhage after adult tonsillectomy. Laryngoscope. 20I4;I24:I554-56.

74 Windfuhr JP, Toepfner N, Steffen G, Waldfahrer F, Berner R. Clinical practice guideline: tonsillitis II. Surgical management. Eur Arch Otorhinolaryngol. 20I6;273:989-I009.

75 Gerbershagen HJ, Aduckathil S, van Wijck AJ, Peelen LM, Kalkman CJ, Meissner W. Pain intensity on the first day after surgery: a prospective cohort study comparing I79 surgical procedures. Anesthesiology. 2013;II8:934-44.

76 Guntinas-Lichius O, Geissler K, Komann M, Schlattmann P, Meissner W. Inter-Hospital Variability of Postoperative Pain after Tonsillectomy: Prospective Registry-Based Multicentre Cohort Study. PLoS One. 20I6;II:eoI54I55. 
77 Sarny S, Habermann W, Ossimitz G, Stammberger H. Significant posttonsillectomy pain is associated with increased risk of hemorrhage. Ann Otol Rhinol Laryngol. 20I2;I2I:776-8I.

78 Pinder DK, Wilson H, Hilton MP. Dissection versus diathermy for tonsillectomy. Cochrane Database Syst Rev. 20II;CDoo22II.

79 Cardozo AA, Hallikeri C, Lawrence H, Sankar V, Hargreaves S. Teenage and adult tonsillectomy: dose-response relationship between diathermy energy used and morbidity. Clin Otolaryngol. 2007;32:366-7I.

80 Geissler K, Ducke M, Volk GF, Meissner W, Guntinas-Lichius O. Pain on the first postoperative day after tonsillectomy in adults: A comparison of metamizole versus etoricoxib as baseline analgesic. PLoS One. 2019; I4:e022II88.

8I Paganelli A, Ayari Khalfallah S, Brunaud A, et al. Guidelines (short version) of the French Oto-Rhino-Laryngology--Head and Neck Surgery Society (SFORL) for the management of post-tonsillectomy pain in adults. Eur Ann Otorhinolaryngol Head Neck Dis. 20I4;I3I:227-32.

82 Ericsson E, Brattwall M, Lundeberg S. Swedish guidelines for the treatment of pain in tonsil surgery in pediatric patients up to I8 years. Int $J$ Pediatr Otorhinolaryngol. 2015;79:443-50.

83 Sarny S, Ossimitz G, Habermann W, Stammberger H. Hemorrhage following tonsil surgery: a multicenter prospective study. Laryngoscope. 20II;I2I:2553-60.

84 Windfuhr JP, Chen YS, Remmert S. Hemorrhage following tonsillectomy and adenoidectomy in I5,2I8 patients. Otolaryngol Head Neck Surg. 2005;132:28I-86.

85 Tomkinson A, Harrison W, Owens D, Harris S, McClure V, Temple M. Risk factors for postoperative hemorrhage following tonsillectomy. Laryngoscope. 20II;I2I:279-88.

86 Shay S, Shapiro NL, Bhattacharyya N. Revisit rates and diagnoses following pediatric tonsillectomy in a large multistate population. Laryngoscope. 2015;125:457-6I.

87 Bhattacharyya N. Evaluation of post-tonsillectomy bleeding in the adult population. Ear Nose Throat J. 200I; 80:544-59.

88 Lowe D, van der Meulen J, Cromwell D, et al. Key messages from the National Prospective Tonsillectomy Audit. Laryngoscope. 2007;II7:7I724 .

89 Walker P, Gillies D. Post-tonsillectomy hemorrhage rates: are they technique-dependent? Otolaryngol Head Neck Surg. 2007;I36:S27-3I.

90 Kvaerner KJ. Benchmarking surgery: secondary post-tonsillectomy hemorrhage 1999-2005. Acta Otolaryngol. 2009; I29:I95-98.

9I Tolska HK, Takala A, Pitkäniemi J, Jero J. Post-tonsillectomy haemorrhage more common than previously described--an institutional chart review. Acta Otolaryngol. 20I3; I33:I8I-86.

92 Ikoma R, Sakane S, Niwa K, Kanetaka S, Kawano T, Oridate N. Risk factors for post-tonsillectomy hemorrhage. Auris, nasus, larynx.

2OI4;4I:376-79. 
93 Windfuhr JP, Verspohl BC, Chen YS, Dahm JD, Werner JA. Posttonsillectomy hemorrhage--some facts will never change. Eur Arch Otorhinolaryngol. 2015;272:I2II-I8.

94 Sarny S, Habermann W, Ossimitz G, Stammberger H. [The Austrian Tonsil Study 2010 - Part 2: Postoperative haemorrhage]. Laryngorhinootologie. 20I2;9I:98-I02.

95 Heidemann CH, Wallen M, Aakesson M, Skov P, Kjeldsen AD, Godballe C. Post-tonsillectomy hemorrhage: assessment of risk factors with special attention to introduction of coblation technique. Eur Arch

Otorhinolaryngol. 2009;266:IOII-I5.

96 Amir I, Belloso A, Broomfield SJ, Morar P. Return to theatre in secondary post-tonsillectomy haemorrhage: a comparison of coblation and dissection techniques. Eur Arch Otorhinolaryngol. 20I2;269:667-7I.

97 Riggin L, Ramakrishna J, Sommer DD, Koren G. A 2013 updated systematic review \& meta-analysis of 36 randomized controlled trials; no apparent effects of non steroidal anti-inflammatory agents on the risk of bleeding after tonsillectomy. Clin Otolaryngol. 20I3;38:II5-29.

98 Bannister M, Thompson C. Post-tonsillectomy dietary advice and haemorrhage risk: Systematic review. Int J Pediatr Otorhinolaryngol. 20I7;IO3:29-3I.

99 Hessen Söderman AC, Ericsson E, Hemlin C, et al. Reduced risk of primary postoperative hemorrhage after tonsil surgery in Sweden: results from the National Tonsil Surgery Register in Sweden covering more than Io years and 54,696 operations. Laryngoscope. 20II;I2I:2322-26.

Ioo Grimes DA, Schulz KF. Cohort studies: marching towards outcomes. Lancet. 2002;359:34I-45.

IOI Vandenbroucke JP. Observational research, randomised trials, and two views of medical science. PLoS Med. 2008;5:e67.

I02 Vandenbroucke JP. What is the best evidence for determining harms of medical treatment? CMAJ. 2006;174:645-46.

I03 Papanikolaou PN, Christidi GD, Ioannidis JP. Comparison of evidence on harms of medical interventions in randomized and nonrandomized studies. CMAJ. 2006;I74:635-4I.

I04 von Elm E, Altman DG, Egger M, et al. The Strengthening the Reporting of Observational Studies in Epidemiology (STROBE) Statement: guidelines for reporting observational studies. Int J Surg. 20I4;I2:I495-99.

I05 McCulloch P, Altman DG, Campbell WB, et al. No surgical innovation without evaluation: the IDEAL recommendations. Lancet. 2009;374:II05I2.

Io6 Hirst A, Philippou Y, Blazeby J, et al. No Surgical Innovation Without Evaluation: Evolution and Further Development of the IDEAL Framework and Recommendations. Ann Surg. 2019;269:2II-20.

I07 Ludvigsson JF, Andersson E, Ekbom A, et al. External review and validation of the Swedish national inpatient register. BMC Public Health. 2OII;II:450. 
I08 The Nordic Medico-Statistical Committee. NOMESCO Classification of Surgical Procedures (NCSP). Copenhagen; 20I0. Yearly updates in Norwegian available from the Norwegian Directorate for e-health: www.ehelse.no

I09 Stalfors J, Brattwall M, Ericsson E, et al. Annual Report 2012 of The National Tonsil Surgery Register in Sweden. Gothenburg, Sweden: Registercentrum Västra Götaland; 2013.

IIO Odhagen E, Sunnergren O, Söderman AH, Thor J, Stalfors J. Reducing post-tonsillectomy haemorrhage rates through a quality improvement project using a Swedish National quality register: a case study. Eur Arch Otorhinolaryngol. 20I8;275:I63I-39.

III Stalfors J, Ericsson E, Hemlin C, Hessen Söderman AC, Odhagen E, Sunnergren O. Annual Report 2013 of The National Tonsil Surgery Register in Sweden. Karolinska Univeristy Hospital, Stockholm, Sweden; 2014.

II2 Elinder K, Söderman AC, Stalfors J, Knutsson J. Factors influencing morbidity after paediatric tonsillectomy: a study of I8,7I2 patients in the National Tonsil Surgery Register in Sweden. Eur Arch Otorhinolaryngol. 20I6;273:2249-56.

II3 Alm F, Stalfors J, Nerfeldt P, Ericsson E. Patient reported pain-related outcome measures after tonsil surgery: an analysis of 32,225 children from the National Tonsil Surgery Register in Sweden 2009-20I6. Eur Arch Otorhinolaryngol. 2017;274:37II-22.

II4 Ruohoalho J, Østvoll E, Bratt M, et al. Systematic review of tonsil surgery quality registers and introduction of the Nordic Tonsil Surgery Register Collaboration. Eur Arch Otorhinolaryngol. 2018;275:1353-63.

II5 Brooke HL, Talbäck M, Hörnblad J, et al. The Swedish cause of death register. Eur J Epidemiol. 20I7;32:765-73.

II6 Paradise JL, Bluestone CD, Bachman RZ, et al. History of recurrent sore throat as an indication for tonsillectomy. Predictive limitations of histories that are undocumented. New Engl J Med. 1978;298:409-I3.

II7 Koshy E, Watt H, Curcin V, Bottle A, Sharland M, Saxena S. Tonsillectomy among children with low baseline acute throat infection consultation rates in UK general practices: a cohort study. BMJ Open. 20I5;5:eoo6686.

II Liu JH, Anderson KE, Willging JPet al. Posttonsillectomy hemorrhage: what is it and what should be recorded? Arch Otolaryngol Head Neck Surg. 200I;I27:I27I-75.

II9 Windfuhr JP. Lethal post-tonsillectomy hemorrhage. Auris Nasus Larynx 2003;30:39I-96.

I20 Blakley BW. Post-tonsillectomy bleeding: how much is too much? Otolaryngol Head Neck Surg. 2009;140:288-90.

I2I Perkins JN, Liang C, Gao D, Shultz L, Friedman NR. Risk of posttonsillectomy hemorrhage by clinical diagnosis. Laryngoscope. 20I2;I22:23II-I5. 
I22 Hoddeson EK, Gourin CG. Adult tonsillectomy: current indications and outcomes. Otolaryngol Head Neck Surg. 2009;I40:I9-22.

I23 Wong Chung J, van Benthem PPG, Blom HM. Tonsillotomy versus tonsillectomy in adults suffering from tonsil-related afflictions: a systematic review. Acta Otolaryngol. 20I8;138:492-50I.

I24 Rakover Y, Almog R, Rosen G. The risk of postoperative haemorrhage in tonsillectomy as an outpatient procedure in children. Int J Pediatr Otorhinolaryngol. 1997;4I:29-36.

I25 Ferary M, Biet A, Strunski V, Page C. Impact of the mode of hospitalisation on the postoperative complication rate after dissection tonsillectomy in children. Eur Ann Otorhinolaryngol Head Neck Dis. 20I4;I3I:345-49.

I26 Mahadevan M, van der Meer G, Gruber M, et al. The starship children's hospital tonsillectomy: A further Io years of experience. Laryngoscope. 20I6;I26:E4I6-E420.

I27 Davies DD. Anaesthetic Mortality in Tonsillectomy and Adenoidectomy. British J Anaesth. I964;36:IIO-I4.

I28 Rasmussen N. Complications of tonsillectomy and adenoidectomy. Otolaryngologic Clin North Am. 1987;20:383-90.

I29 Tate N. Deaths from Tonsillectomy. Lancet. I963;2:I090-I.

I30 Stevenson AN, Myer CM, 3rd, Shuler MD, Singer PS. Complications and legal outcomes of tonsillectomy malpractice claims. Laryngoscope. 20I2;I22:7I-74.

I3I Windfuhr JP, Wienke A, Chen YS. Electrosurgery as a risk factor for secondary post-tonsillectomy hemorrhage. Eur Arch Otorhinolaryngol. 2009;266:III-I6.

I32 Nemati S, Banan R, Kousha A. Bipolar radiofrequency tonsillotomy compared with traditional cold dissection tonsillectomy in adults with recurrent tonsillitis. Otolaryngol Head Neck Surg. 20I0;143:42-47.

I33 Gudnadottir G, Tennvall GR, Stalfors J, Hellgren J. Indirect costs related to caregivers' absence from work after paediatric tonsil surgery. Eur Arch Otorhinolaryngol. 2017;274:2629-36.

I34 Morad A, Sathe NA, Francis DO, McPheeters ML, Chinnadurai S. Tonsillectomy Versus Watchful Waiting for Recurrent Throat Infection: A Systematic Review. Pediatrics. 20I7;I39:e20I63490.

I35 Foki E, Seemann R, Stelter K, Lill C. The effect of tonsillotomy on chronic recurrent tonsillitis in children. Acta Otolaryngol. 20I7;137:99296.

I36 Reichel O, Mayr D, Winterhoff J, de la Chaux R, Hagedorn H, Berghaus A. Tonsillotomy or tonsillectomy?--a prospective study comparing histological and immunological findings in recurrent tonsillitis and tonsillar hyperplasia. Eur Arch Otorhinolaryngol. 2007;264:277-84.

I37 Hoey AW, Foden NM, Hadjisymeou Andreou S, et al. Coblation((R)) intracapsular tonsillectomy (tonsillotomy) in children: A prospective study of 500 consecutive cases with long-term follow-up. Clin Otolaryngol. 20I7;42:I2II-I7. 
I38 Morton V, Torgerson DJ. Effect of regression to the mean on decision making in health care. BMJ. 2003;326:I083-84.

I39 Läkemedelsverket (The Swedish Medical Product Agency). Handläggning av faryngotonsilliter i öppenvård (How to handle pharyngotonsillitis in an outpatient setting). Information från Läkemedelsverket (Information from the Swedish Medical Product Agency); 20I2;23:I8-25. (Available in Swedish from https://lakemedelsverket.se/faryngotonsillit)

I40 Lescanne E, Chiron B, Constant I, et al. Pediatric tonsillectomy: clinical practice guidelines. Eur Ann Otorhinolaryngol Head Neck Dis. 20I2;I29:264-7I.

I4I World Health Organization (WHO). International Classification of Diseases II $^{\text {th }}$ Revision - The global standard for diagnostic health information. Available at https://icd.who.int/en Accessed oct. 2019.

I42 Forsberg L Rydh H, Jacobsson A, Nyquist K, Heurgren M. Kvalitet och innehåll i patientregistret. Utskrivningar från slutenvården I964-2007 och besök i specialiserad öppenvård (exclusive primärvårdsbesök) I997-2007. (Quality and content of the Patient Register). Article number 2009-I25-I5). Published 2009 of The National Board of Health and Welfare at www.socialstyrelsen.se

I43 Rubie I, Haighton C, O'Hara J, et al. The NAtional randomised controlled Trial of Tonsillectomy IN Adults (NATTINA): a clinical and costeffectiveness study: study protocol for a randomised control trial. Trials. 20I5;I6:263.

I44 McSweeney LA, Wilson JA, Wilkes S, Haighton CA. Is Scottish Intercollegiate Guidelines Network guidance for GP management of tonsillitis suitable? A qualitative study. Fam Pract. 20I8;35:633-37.

I45 Walner DL, Karas A. Standardization of reporting post-tonsillectomy bleeding. Ann Otol Rhinol Laryngol. 2013;122:277-82. 
Appendix 


\section{Tonsilloperation peroperativ enkät.}

Reviderad version 161110

* obligatoriskt
Personnummer:

Namn:

e-post:

Datum när enkäten fylls i:

Operationsdatum*:
Huvudindikation* (endast ett alternativ)

$\square$ Luftvägsobstruktion/snarkning /hypertrofa tonsiller

$\square$ Upprepade tonsilliter

$\square$ Peritonsillit

$\square$ Kronisk tonsillit

$\square$ Systemkomplikation till tonsillit

$\square$ Om annat, specificera:

\section{Operationsteknik}

$\square$ Kallt stål

Radiofrekvens

$\square$ Diatermisax

$\square$ Ultracision

$\square$ Dissektion med bipolär diatermi

$\square$ Annan, nämligen:

\section{Vårdform}

$\square$ Dagkirurgi $\square$ Slutenvård

Tonsillektomi à chaud

$\square$ Ja $\quad \square$ Nej

\section{Operationsmetod*}

$\square$ Tonsillektomi EMB10

$\square$ Tonsillektomi + abrasio EMB20

$\square$ Tonsillotomi EMB15

$\square$ Tonsillotomi + abrasio EMB15 + EMB30

Blodstillningsmetod (utöver kompression)

$\square$ Infiltrationsanestesi med adrenalin

$\square$ Unipolär diatermi

$\square$ Bipolär diatermi

$\square$ Ligatur

$\square$ Suturligatur (omstickning)

$\square$ Radiofrekvens

$\square$ Annan, nämligen:

\section{Blödningskomplikationer}

Postoperativ blödning som krävt åtgärd?

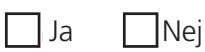

Om ja, vilken åtgärd?

$\square$ Cyklokapron/Octostim

$\square$ Stillande av blödning i narkos

$\square$ Transfusion

$\square$ Annat

Läkarens namn:

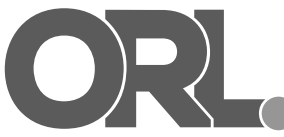

Tonsilloperationsregistret, ÖNH-registret, Registercentrum Västra Götaland, 41345 Göteborg. 



\section{PATIENTENKÄT}

Fylls i 30 dagar efter tonsilloperation

Reviderad version (180301)

Du/ditt barn har blivit opererad för halsmandlarna för ca 30 dagar sedan. För att kunna förbättra vården är det viktigt att få veta om komplikationer har uppstått efter operationen. Vi är angelägna om dina/ditt barns svar även om allt har varit besvärsfritt. Om du är vårdnadshavare eller annan anhörig vill vi att du besvarar frågorna som du tror att barnet upplever sin situation.

Tack på förhand för Din medverkan!

Namn:

Patientens personnummer:

\section{Epostadress:}

(6 månader efter genomförd operation kommer du återigen tillfrågas att besvara en enkät. Om du önskar att den skickas via epost, ange här aktuell epostadress.)

Datum för ifyllandet av enkäten:

Du som fyller i enkäten är den som opererats anhörig/annan

Har du kontaktat sjukvården på grund av blödning från halsen? $\square$ Ja $\square$ Nej Om Ja, hur många dagar efter operationen började det blöda?

Har du blivit inlagd på sjukhus på grund av blödning från halsen? $\square$ Ja $\square$ Nej Om Ja, på vilket sjukhus blev du inlagd?

Utfördes ytterligare operation p g a blödning?

$\square$ Ja $\square$ Nej

Uppstod någon infektion under vårdtiden eller inom 30 dagar efter operationen?

Om Ja, vilken sorts infektion?

Har du kontaktat sjukvården på grund av infektionen?

Har du fått antibiotikabehandling på grund av infektionen?

Har du kontaktat sjukvården på grund av smärta efter operationen?

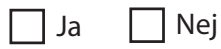

Hur många dagar efter operation tog du smärtstillande läkemedel?

Hur många dagar efter operation började du äta vanlig mat?

Har informationen som du fått, stämt med hur du upplevde operationen

och tiden efter?

$\square$ Ja $\square$ Nej

Om Nej, vad stämde inte?

Har du tagit del av patientinformationen på www.tonsilloperation.se? 



\section{PATIENTENKÄT}

Fylls i 6 månader efter tonsilloperation

Reviderad version (161110)

Du/ditt barn har blivit opererad för halsmandlarna för ca 6 månader sedan. För att kunna förbättra vården är det viktigt att få veta hur dina/ditt barns besvär har förändrats efter operationen. Om du är vårdnadshavare eller annan anhörig vill vi att du besvarar frågorna om hur du tror att barnet upplever sin situation. Tack på förhand för Din medverkan!

Namn:

Patientens personnummer:

Datum för ifyllandet av enkäten:

Du som fyller i enkäten är $\quad \square$ den som opererats $\quad \square$ anhörig/annan

\section{Sätt kryss i den ruta som bäst stämmer in på Din/Ditt barns situation:}

Besvären är borta

$\square$ Jag har blivit ganska bra från mina besvär

Jag har kvar mina besvär

Mina besvär har förvärrats

Har Du/Ditt barn fått andra besvär? $\quad \square$ Ja $\square$ Nej

Om Ja, vilka?

Eventuella kommentarer:

Tonsilloperationsregistret ÖNH-registret, Registercentrum Västra Götaland, 41345 Göteborg ordförande Joacim Stalfors joacim@stalfors.se 
